\title{
Influence of diet on the gut microbiome and implications for human health
}

\author{
Rasnik K. Singh ${ }^{1}$, Hsin-Wen Chang ${ }^{2}$, Di Yan² ${ }^{2}$ Kristina M. Lee², Derya Ucmak², Kirsten Wong ${ }^{2}$, Michael Abrouk ${ }^{3}$, \\ Benjamin Farahnik ${ }^{4}$, Mio Nakamura ${ }^{2}$, Tian Hao Zhu ${ }^{5}$, Tina Bhutani ${ }^{2}$ and Wilson Liao ${ }^{2^{*}}$ (D)
}

\begin{abstract}
Recent studies have suggested that the intestinal microbiome plays an important role in modulating risk of several chronic diseases, including inflammatory bowel disease, obesity, type 2 diabetes, cardiovascular disease, and cancer. At the same time, it is now understood that diet plays a significant role in shaping the microbiome, with experiments showing that dietary alterations can induce large, temporary microbial shifts within $24 \mathrm{~h}$. Given this association, there may be significant therapeutic utility in altering microbial composition through diet. This review systematically evaluates current data regarding the effects of several common dietary components on intestinal microbiota. We show that consumption of particular types of food produces predictable shifts in existing host bacterial genera. Furthermore, the identity of these bacteria affects host immune and metabolic parameters, with broad implications for human health. Familiarity with these associations will be of tremendous use to the practitioner as well as the patient.
\end{abstract}

Keywords: Diet, Health, Metabolism, Microbiome, Microbiota, Nutrition

\section{Background}

\section{The gut microbiome}

The human gut microbiome encompasses $10^{14}$ resident microorganisms, including bacteria, viruses, fungi, and protozoa, that are commensal with the human intestinal tract [1]. Among these, bacteria represent the most well studied group and will be the main focus of this review. Overall the predominant bacterial groups in the microbiome are gram positive Firmicutes and gram negative Bacteroidetes [2,3]. Recently, it has been shown that microbiota can effectively be subdivided into different enterotypes, each enriched by particular bacterial genera, but that all seem to share high functional uniformity [4]. This uniformity exists regardless of several host properties, such as age, sex, body mass index, and nationality [5].

The majority of microorganisms reside within the more distal parts of the digestive tract, where their biomass surpasses $10^{11}$ cells per gram content [6]. Microbes

\footnotetext{
*Correspondence: wilson.liao@ucsf.edu

${ }^{2}$ Department of Dermatology, University of California, San Francisco, 2340 Sutter St. Room N431, Box 0808, San Francisco, CA 94115, USA Full list of author information is available at the end of the article
}

in the distal gut contribute to host health through biosynthesis of vitamins and essential amino acids, as well as generation of important metabolic byproducts from dietary components left undigested by the small intestine [7]. Short chain fatty acid (SCFA) byproducts such as butyrate, propionate, and acetate act as a major energy source for intestinal epithelial cells and may therefore strengthen the mucosal barrier [8]. Additionally, studies conducted using germ-free mice suggest that the microbiota directly promote local intestinal immunity through their effects on toll-like receptor (TLR) expression [9], antigen presenting cells, differentiated $\mathrm{T}$ cells, and lymphoid follicles $[10,11]$, as well as by affecting systemic immunity through increased splenic $\mathrm{CD} 4^{+} \mathrm{T}$ cells and systemic antibody expression [12].

These recorded benefits and more have led to growing interest in the ability to modify the gut microbiota. An acute change in diet-for instance to one that is strictly animal-based or plant-based-alters microbial composition within just $24 \mathrm{~h}$ of initiation, with reversion to baseline within $48 \mathrm{~h}$ of diet discontinuation [13]. Furthermore, the gut microbiome of animals fed a high-fat or high-sugar diet is more prone to circadian rhythm disruption [14]. Studies also suggest that overwhelming 
systemic stress and inflammation-such as that induced via severe burn injury-can also produce characteristic acute changes in the gut microbiota within just one day of the sustained insult [15].

\section{The microbiome in disease}

Studies examining the composition and role of the intestinal microbiome in different disease states have uncovered associations with inflammatory bowel diseases (IBD), inflammatory skin diseases such as psoriasis and atopic dermatitis, autoimmune arthritis, type 2 diabetes, obesity, and atherosclerosis. For instance, IBD patients tend to have less bacterial diversity as well as lower numbers of Bacteroides and Firmicutes-which together may contribute to reduced concentrations of microbial-derived butyrate. Butyrate and other SCFAs are thought to have a direct anti-inflammatory effect in the gut [16]. Furthermore, different indices of Crohn's disease activity have each been characterized by specific gut mucosa-attached bacteria, that in turn are significantly influenced by anti-TNF therapy [17]. The relative abundance of different bacteria may mediate intestinal inflammation and Crohn's disease activity through effects on local regulatory $\mathrm{T}$ cell populations $[17,18]$. Furthermore, overrepresentation analysis has shown that enzymes enriched in IBD microbiomes are more frequently involved in membrane transport, which could support a "leaky gut hypothesis" contributing to the disease state $[19,20]$. Interestingly, autoimmune Th17 differentiation from naïve $\mathrm{T}$ cells appears to be dependent on the segmented filamentous bacteria. Studies have shown that Th17 cells are absent in the small-intestinal lamina propria of germ-free animals, which is the major site of their differentiation. Furthermore, introduction of segmented filamentous bacteria is sufficient to trigger autoimmune arthritis in these animals through promotion of Th17 cell development in the lamina propria and spleen $[20,21]$. The gut microbiota of patients with type 2 diabetes has been functionally characterized with diabetes-associated markers, showing enriched membrane transport of sugars and branched-chain amino acids, xenobiotic metabolism, and sulphate reduction along with decreased bacterial chemotaxis, butyrate synthesis and metabolism of cofactors and vitamins [22]. Obesity has been characterized by an altered intestinal Bacteroides:Firmicutes ratio, with greater relative abundance of Firmicutes. Furthermore, studies involving microbiota transplantation from obese to lean mice have shown that the obese phenotype is transmissible and may be promoted by microbiota that have increased capacity to harvest energy from the host diet [23]. Risk of atherosclerosis has similarly been linked to the gut microbiota, in particular due to enhanced metabolism of choline and phosphatidylcholine that produces the proatherogenic compound, trimethylamine-N-oxide (TMAO) [24]. A recent study also demonstrated that gut bacteria can produce significant amounts of amyloid and lipopolysaccharides, which are key players in the pathogenesis of Alzheimer's disease [25]. These observations illustrate the important role of microorganisms in human health and suggest that manipulating them may influence disease activity. While the microbiome of a healthy individual is relatively stable, gut microbial dynamics can certainly be influenced by host lifestyle and dietary choices [26].

In this review, we comprehensively explore the ability of the host diet to modulate gut bacteria, with the hope that this knowledge will guide our understanding of how dietary choices impact human health through alteration of the gastrointestinal ecosystem (Fig. 1, Table 1).

\section{Methods}

We performed a systematic literature review in September 2015 by searching the electronic MEDLINE database via PubMed. Search terms included combinations of the terms "microbiota", "intestinal mucosa/microbiology", "gastrointestinal tract/microbiology", "gastrointestinal diseases/microbiology", with "diet", "food", "polysaccharides", "carbohydrates", "proteins", "meat", "fat", "lactose", "oligofructose", "prebiotics", "probiotics", "polyphenols", "starch", "soy", "sucrose", "fructose", "diet, vegetarian", "diet, western", "cereals", "dietary fiber", and "dietary supplements". Articles were reviewed independently by two investigators, R.K.S. and K.M.L, and this was adjudicated by W.L. We limited our search to articles available in English, human studies, and those published between 1970 and 2015. We excluded studies that did not explicitly address the effect of a dietary intervention on microbial composition. Manual searches through reference lists of the articles were also performed to identify additional studies. This resulted in a total of 188 articles being selected for inclusion in this review. Studies describing the relationship between specific dietary components and intestinal microbiota composition ranged from subject number $\mathrm{n}=3$ to $\mathrm{n}=344$, with a majority of studies clustered around subject number $\mathrm{n}=20$ to 70. Study designs were primarily randomized controlled trials, cross-sectional studies, case-control studies, and in vitro studies. In addition to human studies, several animal studies were also included to demonstrate dietary impact on the microbiome under controlled experimental conditions.

\section{Diet and microbiota \\ Protein}

The effects of dietary protein on the gut microbiota were first described in 1977. A culture-based study 


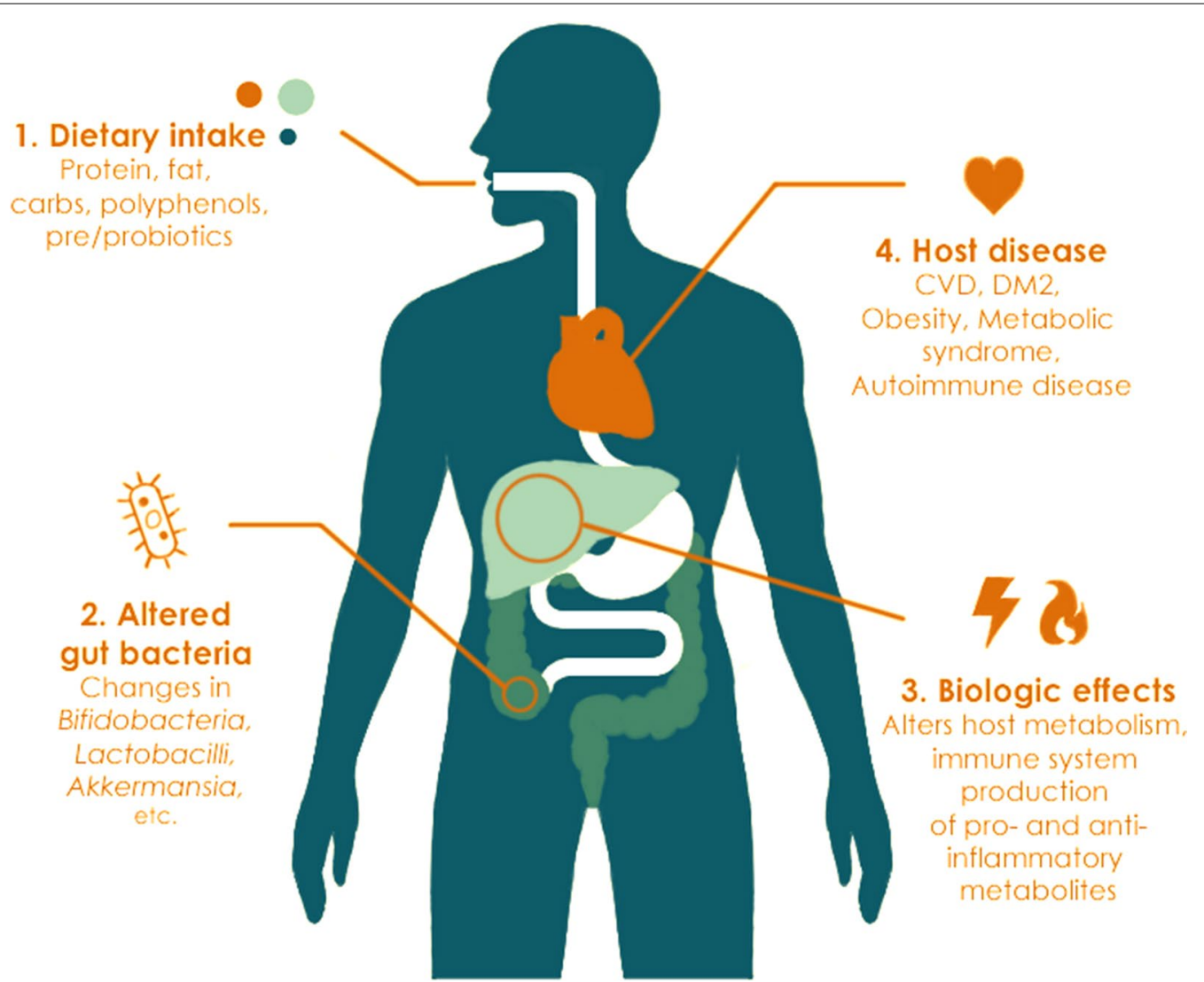

Fig. 1 Impact of diet on the gut microbiome and human health

demonstrated lower counts of Bifidobacterium adolescentis and increased counts of Bacteroides and Clostridia in subjects consuming a high beef diet when compared to subjects consuming a meatless diet [27]. With the advances of 16S rRNA sequencing, several studies have been able to comprehensively investigate the impact of dietary protein on gut microbial composition (studies listed in Table 2). Participants were given different forms of protein across these studies, such as heavy animalbased protein from meats, eggs, and cheeses; whey protein; or purely vegetarian sources such as pea protein. A majority of the studies noted that protein consumption positively correlates with overall microbial diversity $[13,28-30]$. For example, consumption of whey and pea protein extract has been reported to increase gut-commensal Bifidobacterium and Lactobacillus, while whey additionally decreases the pathogenic Bacteroides fragilis and Clostridium perfringens [31-33]. Pea protein has also been observed to increase intestinal SCFA levels, which are considered anti-inflammatory and important for maintenance of the mucosal barrier [34]. On the contrary, counts of bile-tolerant anaerobes such as Bacteroides, Alistipes, and Bilophila were noted to increase with consumption of animal-based protein (Fig. 2) [13, 29, 30]. This observation can be further supported by an independent study in which the researchers compared the microbiota of Italian children with that of children in a rural African village. Italian children, who ate more animal protein, were enriched for Bacteroides and Alistipes in their microbiota [35]. Notably, one study comparing calorically equivalent high animal protein with high-carbohydrate/fiber plant-based diets reported that subjects' weights on the plant-based diet remained stable, but decreased significantly by day 3 of the animal protein-based diet $(\mathrm{q}<0.05)$. Although high protein/low carbohydrate intake may promote greater relative weight loss, this dietary pattern may pose a detriment to health. One study found that subjects with a high protein/low carbohydrate diet have reduced Roseburia and Eubacterium rectale in their gut microbiota and a decreased proportion of butyrate in their feces [36]. In their study, De Filippo et al. [35] similarly noted fewer fecal SCFAs in Italian subjects who consumed a protein-rich diet. As an interesting clinical correlate, several studies have demonstrated that IBD patients possess lower fecal counts of Roseburia and other butyrate-producing bacteria than 
Table 1 Overview of select gut bacterial genera and species commonly affected by diet

\begin{tabular}{|c|c|c|c|c|}
\hline Bacteria & Basic features & Associated physiologic changes & Associated disease states & References \\
\hline Bifidobacterium spp. & $\begin{array}{l}\text { Gram positive obligate anaerobe } \\
\text { branched; nonmotile }\end{array}$ & $\begin{array}{l}\text { SCFA production; improve gut } \\
\text { mucosal barrier; lower intestinal } \\
\text { LPS levels }\end{array}$ & Reduced abundance in obesity & {$[166,167]$} \\
\hline Lactobacillus spp. & $\begin{array}{l}\text { Gram positive facultative anaerobe } \\
\text { rod-shaped }\end{array}$ & $\begin{array}{l}\text { SCFA production; anti-inflammatory } \\
\text { and anti-cancer activities }\end{array}$ & Attenuate IBD & {$[168,169]$} \\
\hline Bacteroides spp. & $\begin{array}{l}\text { Gram negative obligate anaerobe } \\
\text { rod-shaped; variable motility }\end{array}$ & Activate CD4 + T cells & Increased abundance in IBD & {$[170-173]$} \\
\hline Alistipes spp. & $\begin{array}{l}\text { Gram negative obligate anaerobe } \\
\text { rod-shaped; bile-resistant and } \\
\text { pigment-producing }^{\text {a }}\end{array}$ & & $\begin{array}{l}\text { Reported in tissue from acute appen- } \\
\text { dicitis and perirectal and brain } \\
\text { abscesses }\end{array}$ & {$[174]$} \\
\hline Bilophila spp. & $\begin{array}{l}\text { Gram negative obligate anaerobe } \\
\text { urease-positive, bile resistant, } \\
\text { catalase-positive }\end{array}$ & $\begin{array}{l}\text { Promote pro-inflammatory } \mathrm{T}_{\mathrm{H}} 1 \\
\text { immunity }\end{array}$ & $\begin{array}{l}\text { B. wadsworthia observed in colitis, } \\
\text { perforated and gangrenous } \\
\text { appendicitis, liver and soft tissue } \\
\text { abscesses, cholecystitis, FG, empy- } \\
\text { ema, osteomyelitis, and HS }\end{array}$ & {$[175,176]$} \\
\hline Clostridium spp. & $\begin{array}{l}\text { Gram positive obligate anaerobe } \\
\text { rod-shaped; spore-forming }\end{array}$ & Promote generation of $\mathrm{T}_{\mathrm{H}} 17$ cells & $\begin{array}{l}\text { Several spp. are pathogenic causing } \\
\text { tetanus, botulism, gas gangrene, or } \\
\text { pseudomembranous colitis }\end{array}$ & {$[177,178]$} \\
\hline Roseburia spp. & $\begin{array}{l}\text { Gram variable obligate anaerobe } \\
\text { curved rod-shaped; motile }\end{array}$ & SCFA production & Reduced abundance in IBD & {$[179]$} \\
\hline Eubacterium spp. & $\begin{array}{l}\text { Gram positive obligate anaerobe } \\
\text { rod-shaped }\end{array}$ & $\begin{array}{l}\text { SCFA production; form beneficial } \\
\text { phenolic acids }\end{array}$ & Reduced abundance in IBD & {$[180,181]$} \\
\hline Enterococcus spp. & $\begin{array}{l}\text { Gram positive facultative anaerobe } \\
\text { cocci }\end{array}$ & & $\begin{array}{l}\text { Several spp. are pathogenic causing } \\
\text { UTI, endocarditis, or bacteremia }\end{array}$ & {$[182]$} \\
\hline $\begin{array}{l}\text { Faecalibacterium } \\
\text { prausnitzii }\end{array}$ & $\begin{array}{l}\text { Gram positive obligate anaerobe } \\
\text { rod-shaped; nonmotile }\end{array}$ & $\begin{array}{l}\text { SCFA production; anti-inflammatory } \\
\text { effects }\end{array}$ & $\begin{array}{l}\text { Reduced abundance in IBD and } \\
\text { obesity }\end{array}$ & {$[183,184]$} \\
\hline $\begin{array}{l}\text { Akkermansia mucin- } \\
\text { iphila }\end{array}$ & $\begin{array}{l}\text { Gram negative obligate anaerobe } \\
\text { oval-shaped; nonmotile }\end{array}$ & Anti-inflammatory effects & $\begin{array}{l}\text { Reduced abundance in IBD, obesity, } \\
\text { and psoriatic arthritis }\end{array}$ & {$[53,133,185]$} \\
\hline Escherichia coli & $\begin{array}{l}\text { Gram negative facultative anaer- } \\
\text { obe rod-shaped }\end{array}$ & TLR-activation & $\begin{array}{l}\text { Increased abundance in IBD gastroen- } \\
\text { teritis, UTI, and meningitis }\end{array}$ & {$[186-188]$} \\
\hline Helicobacter pylori & $\begin{array}{l}\text { Gram negative microaerophilic } \\
\text { helix-shaped; motile }\end{array}$ & & Gastritis; ulcers; MALT cancers & {$[189,190]$} \\
\hline Streptococcus spp. & $\begin{array}{l}\text { Gram positive facultative anaerobe } \\
\text { cocci }\end{array}$ & & $\begin{array}{l}\text { Some spp. are pathogenic caus- } \\
\text { ing meningitis, pneumonia, and } \\
\text { endocarditis }\end{array}$ & {$[191]$} \\
\hline
\end{tabular}

spp species, SCFA short chain fatty acid, LPS lipopolysaccharide, IBD inflammatory bowel disease, $T_{H}$ T helper, FG Fournier's gangrene, HS hidradenitis suppurativa, UTI urinary tract infection(s), TLR toll-like receptor, MALT mucosa-associated lymphoid tissue

a A. putredinis does not produce pigment and is susceptible to bile

healthy subjects. Healthy subjects, on other other hand, have 10 -fold more abundant $E$. rectale in their intestines [37-39]. These gut bacterial changes may be responsible for the finding in a large participant prospective study $(\mathrm{n}=67,581)$ that high total protein intake, especially animal protein, is associated with a significantly increased risk of IBD [40]. Furthermore, several microbial genera promoted by intake of red meat have also been associated with increased levels of trimethylamine- $\mathrm{N}$-oxide (TMAO), a proatherogenic compound that increases risk of cardiovascular disease [41].

Mouse studies have revealed that high protein intake increases insulin-like growth factor 1 (IGF-1) levels, which are in turn associated with an increased risk of cancer, diabetes, and overall mortality. In one study, plant-derived proteins are associated with lower mortality than animal-derived proteins [42]. Accordingly, longterm practice of such dietary habits may increase risk of colonic disease and others. It is important to note that animal-based diets are often high in fat, in addition to protein. Dietary fat can also affect microbial composition; therefore, further studies will be required to investigate in what capacity each individual macromolecule impacts the bacterial communities and how they act in concert.

\section{Fats}

Consumption of high saturated and trans fat diets is thought to increase the risk of cardiovascular disease through upregulation of blood total- and LDL-cholesterol $[43,44]$. On the other hand health-promoting fats, 
Table 2 Effects of protein on gut microbiota

\begin{tabular}{|c|c|c|c|c|c|c|c|c|c|c|}
\hline & $\begin{array}{l}\text { Microbial } \\
\text { diversity }\end{array}$ & Bifidobacteria & Lactobacilli & Bacteroides & Alistipes & Bilophila & Clostridia & Roseburia & $\begin{array}{l}\text { Eubacterium } \\
\text { Rectale }\end{array}$ & References \\
\hline $\begin{array}{l}\text { Animal } \\
\text { protein }\end{array}$ & $\uparrow$ & $\uparrow \downarrow$ & & $\uparrow \downarrow$ & $\uparrow$ & $\uparrow$ & $\uparrow$ & $\downarrow$ & $\uparrow \downarrow$ & $\begin{array}{c}{[13,29-35,} \\
38-40]\end{array}$ \\
\hline $\begin{array}{l}\text { Whey protein } \\
\text { extract }\end{array}$ & $\uparrow$ & $\uparrow$ & $\uparrow$ & $\downarrow$ & & & $\downarrow$ & & & {$[32,33]$} \\
\hline $\begin{array}{l}\text { Pea protein } \\
\text { extract }\end{array}$ & $\uparrow$ & $\uparrow$ & $\uparrow$ & & & & & & & [31] \\
\hline
\end{tabular}

Arrow thickness corresponds to relative number of studies supporting the relationship

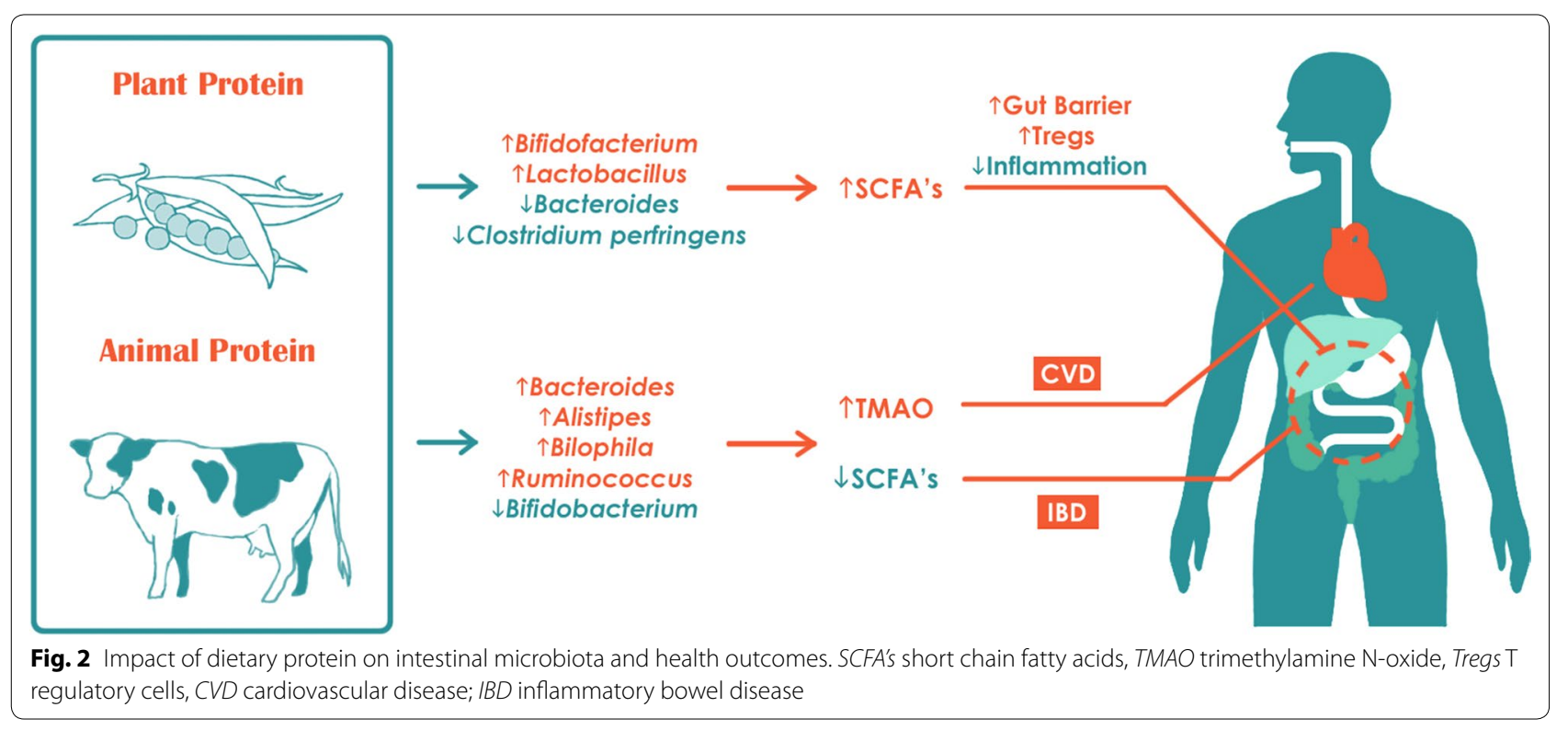

such as mono and polyunsaturated fats, are crucial in alleviating risk of chronic disease. The typical Western diet is both high in saturated and trans fats while low in mono and polyunsaturated fats, therefore predisposing regular consumers to many health problems [45-47]. Several human studies have suggested that a high-fat diet increases total anaerobic microflora and counts of Bacteroides $[26,29,48,49]$ (studies listed in Table 3). To specifically investigate the effects of different kinds of dietary fat on human gut microbiota, Fava et al. had subjects consume diets of varying fat content. The authors noted that consumption of a low fat diet led to increased fecal abundance of Bifidobacterium with concomitant reductions in fasting glucose and total cholesterol, compared to baseline. On the other hand, a high saturated fat diet increased the relative proportion of Faecalibacterium prausnitzii. Finally, subjects with high monounsaturated fat intake did not experience shifts in the relative abundance of any bacterial genera, but did have overall reduced total bacterial load and plasma total- and
LDL-cholesterol [49]. In line with these findings, consumption of salmon-which is high in mono and polyunsaturated fats-was not noted to alter fecal microbiota composition in 123 subjects either [50]. Studies in rats have shown that intake of a high-fat diet results in considerably less Lactobacillus intestinalis and disproportionately more propionate and acetate producing species, including Clostridiales, Bacteroides, and Enterobacteriales. Furthermore, the abundance of Lactobacillus intestinalis is negatively correlated with rat fat mass and body weight [51]. Microbial changes have also been shown to control metabolic endotoxemia-induced inflammation in high-fat diet consuming mice [52]. Mouse studies have also compared the differential effects of various lipids on intestinal microflora. A comparison of lard-derived and fish oil-derived lipids revealed that Bacteroides and Bilophila were increased in lard-fed mice, while Actinobacteria (Bifidobacterium and Adlercreutzia), lactic acid bacteria (Lactobacillus and Streptococcus), and Verrucomicrobia (Akkermansia muciniphila) were increased 
Table 3 Effects of fats on gut microbiota

\begin{tabular}{|c|c|c|c|c|c|c|c|c|}
\hline & $\begin{array}{l}\text { Lactic acid } \\
\text { bacteria }^{\mathrm{a}}\end{array}$ & Bifidobacteria & Clostridiales & Bacteroides & Bilophila & $\begin{array}{l}\text { Faecalibacte- } \\
\text { rium prausnitzii }\end{array}$ & $\begin{array}{l}\text { Akkermansia } \\
\text { muciniphila }\end{array}$ & References \\
\hline High fat & $\downarrow$ & & $\uparrow$ & $\uparrow$ & & & & {$[30,49,51,52]$} \\
\hline Low fat & & $\uparrow$ & & & & & & {$[49]$} \\
\hline High saturated fat & & & & $\uparrow$ & $\uparrow$ & $\uparrow$ & & {$[26,49]$} \\
\hline $\begin{array}{l}\text { High unsaturated } \\
\text { fat }\end{array}$ & $\uparrow$ & $\uparrow$ & & & & & $\uparrow$ & {$[45,49,50]$} \\
\hline
\end{tabular}

a Lactic acid bacteria include Lactobacillus and Streptococcus

in fish-oil-fed mice. Furthermore, lard-fed mice had increased systemic TLR activation, white adipose tissue inflammation, and impaired insulin sensitivity compared to mice consuming fish oil. The authors demonstrated that these findings are at least partly due to differences in gut microbiota between the two groups; transplantation of microbiota from one group to the other after antibiotic administration not only enriched the transplant recipient's gut with dominant genera from the donor species, but also replicated the donor's inflammatory and metabolic phenotypes. These results indicate that gut microbiota may promote metabolic inflammation through TLR signaling upon challenge with a diet rich in saturated lipids (Fig. 3) [53].

\section{Carbohydrates}

\section{Digestible carbohydrates (starch, sugars)}

Carbohydrates are possibly the most well studied dietary component for their ability to modify the gut microbiome (studies listed in Table 4). Carbohydrates exist in two varieties: digestible and non-digestible. Digestible carbohydrates are enzymatically degraded in the small intestine and include starches and sugars, such as glucose, fructose, sucrose, and lactose. Upon degradation, these compounds release glucose into the bloodstream and stimulate an insulin response [54]. Human subjects fed high levels of glucose, fructose, and sucrose in the form of date fruits [55] had increased relative abundance of Bifidobacteria, with reduced Bacteroides [56]. In a separate study, the addition of lactose to the diet replicated these same bacterial shifts while also decreasing Clostridia species. Notably, many Clostridium cluster XIVa species have been associated with irritable bowel syndrome [57, 58]. Lactose supplementation has additionally been observed to increase the fecal concentration of beneficial SCFAs [58]. These findings are quite unexpected given that lactose is commonly thought of as a potential gastrointestinal irritant (e.g. lactose intolerance). Further studies validating these observations can help clarify the effects of lactose.

The artificial sweeteners saccharin, sucralose, and aspartame represent another dietary controversy.

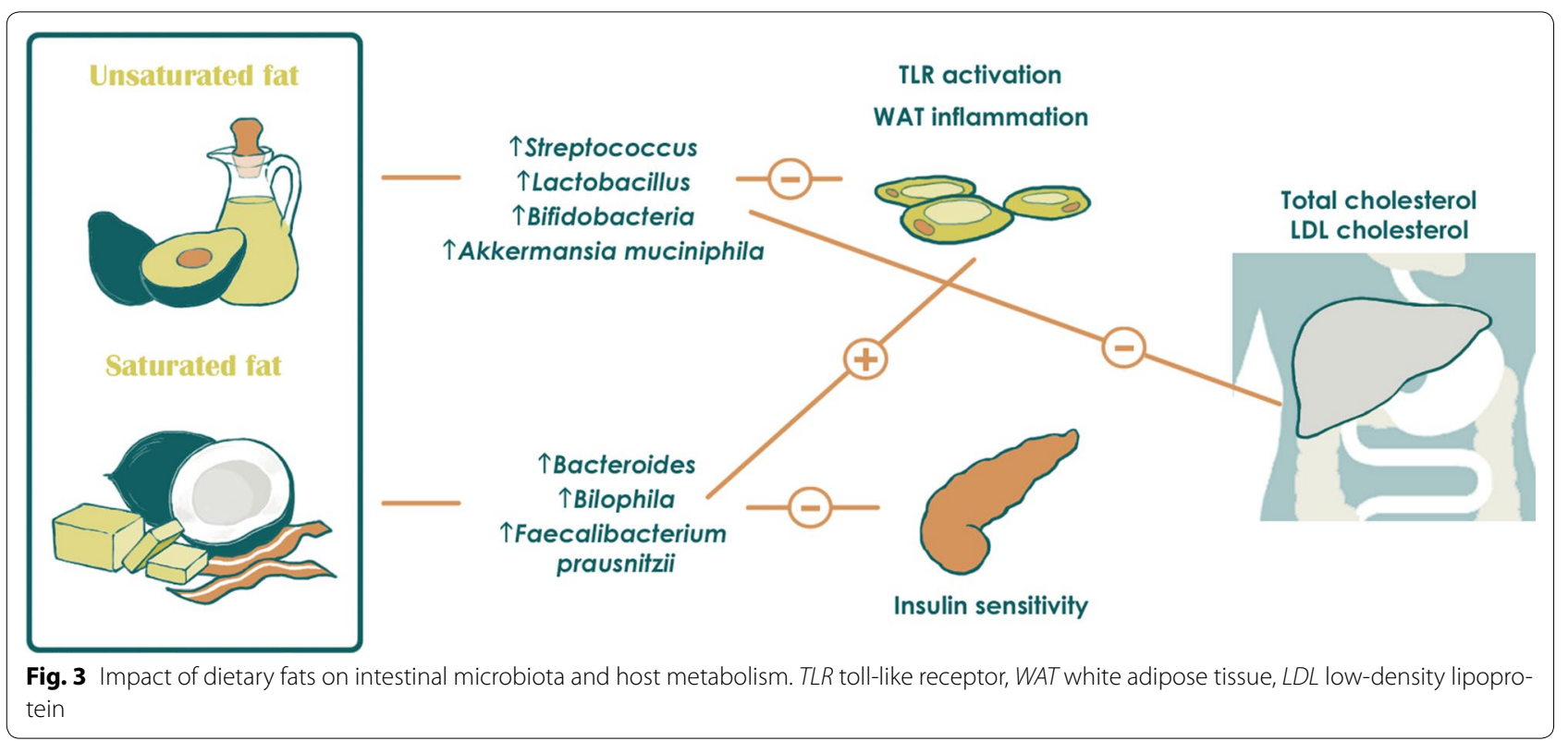


Table 4 Effects of natural and artificial sugar on gut microbiota

\begin{tabular}{llllll}
\hline & Bifidobacteria & Bacteroides & Clostridia & Lactobacilli & References \\
\hline Glucose & $\uparrow$ & $\downarrow$ & & & {$[55,56]$} \\
Fructose & $\uparrow$ & $\downarrow$ & & {$[55,56]$} \\
Sucrose & $\uparrow$ & $\downarrow$ & $\downarrow$ & $\uparrow$ & {$[55,56]$} \\
Lactose & $\uparrow$ & $\downarrow$ & $\downarrow$ & $\downarrow$ & {$[58]$} \\
Artificial sweeteners & $\downarrow$ & $\uparrow$ & $\downarrow$ & {$[59]$} \\
\hline
\end{tabular}

Artificial sweeteners were originally marketed as a health-conscious, no-calorie food option that could be used to replace natural sugar. Recent evidence from Suez et al. suggests that consumption of all types of artificial sweeteners is actually more likely to induce glucose intolerance than consumption of pure glucose and sucrose. Interestingly, artificial sweeteners are thought to mediate this effect through alteration of gut microbiota. For instance, saccharin-fed mice were noted to have intestinal dysbiosis with increased relative abundance of Bacteroides and reduced Lactobacillus reuteri [59]. These microbial shifts directly oppose those induced by intake of natural sugars (glucose, fructose, and sucrose)as mentioned above. The evidence seems to suggest that, contrary to popular belief, artificial sweeteners may actually be unhealthier to consume than natural sugars.

\section{Non-digestible carbohydrates (fiber)}

In contrast to digestible carbohydrates, non-digestible carbohydrates such as fiber and resistant starch are not enzymatically degraded in the small intestine. Rather, they travel to the large intestine where they undergo fermentation by resident microorganisms. Accordingly, dietary fiber is a good source of "microbiota accessible carbohydrates" (MACs), which can be utilized by microbes to provide the host with energy and a carbon source $[25,60,61]$. In the process, they are able to modify the intestinal environment. This property of fibers warrants their additional designation as prebiotics, which by definition are non-digestible dietary components that benefit host health via selective stimulation of the growth and/or activity of certain microorganisms [62]. Sources of prebiotics include soybeans, inulins, unrefined wheat and barley, raw oats, and non-digestible oligosaccharides such as fructans, polydextrose, fructooligosaccharides (FOS), galactooligosaccharides (GOS), xylooligosaccharides (XOS), and arabinooligosaccharides (AOS) [63]. A diet that is low in these substances has been shown to reduce total bacterial abundance [64]. On the other hand, high intake of these carbohydrates in 49 obese subjects resulted in an increase in microbiota gene richness [30]. Regarding their effects on specific bacterial genera, many studies suggest that a diet rich in non-digestible carbohydrates most consistently increases intestinal bifidobacteria and lactic acid bacteria (studies listed in Table 5). The numerous studies listed in Table 5 corresponding to each type of prebiotic listed above, corroborate these findings. For instance, non-digestible carbohydrate diets that are rich in whole grain and wheat bran are linked to an increase in gut Bifidobacteria and Lactobacilli $[65,66]$. Other non-digestible carbohydrates, such as resistant starch and whole grain barley, appear to also increase abundance of Ruminococcus, E. rectale, and Roseburia [3, 67, 68]. Additionally, FOS-, polydextrose-, and AOS-based prebiotics have been observed to reduce Clostridium [69-72] and Enterococcus species [73-76]. A cross-sectional study of 344 patients with advanced colorectal adenomas revealed that Roseburia and Eubacterium were significantly less prevalent, while Enterococcus and Streptococcus were more prevalent in these subjects compared to healthy controls. Reduced dietary fiber habits and consistently lower SCFA production were also observed in the adenoma group [77].

Table 5 Effects of non-digestible carbohydrates on gut microbiota

\begin{tabular}{|c|c|c|c|c|c|c|c|c|c|c|}
\hline & $\begin{array}{l}\text { Bacterial } \\
\text { abundance }\end{array}$ & $\begin{array}{l}\text { Gene } \\
\text { richness }\end{array}$ & Lactobacilli & Bifidobacteria & Clostridia & Enterococcus & Roseburia & Eubacteria & Ruminococcus & References \\
\hline $\begin{array}{l}\text { Fiber/prebi- } \\
\text { otics }\end{array}$ & $\uparrow$ & $\uparrow$ & $\uparrow$ & $\uparrow$ & $\downarrow$ & $\uparrow \downarrow$ & & & & $\begin{array}{c}{[30,64-66} \\
69-76]\end{array}$ \\
\hline $\begin{array}{l}\text { Resistant } \\
\text { starch }\end{array}$ & $\uparrow$ & $\uparrow$ & $\uparrow$ & $\uparrow$ & & & $\uparrow$ & $\uparrow$ & $\uparrow$ & $\begin{array}{c}{[3,30} \\
67-69 \\
72-74]\end{array}$ \\
\hline
\end{tabular}


In addition to their effects on the makeup of the microbiota, and likely partially mediated by these effects, prebiotics also produce notable shifts in metabolic and immune markers. For instance, several groups observed reductions in the proinflammatory cytokine IL-6, insulin resistance, and peak post-prandial glucose associated with intake of non-digestible carbohydrates present in whole grains $[67,78,79]$. One group additionally observed reductions in total body weight and concentrations of serum triglycerides, total cholesterol, LDLcholesterol, and hemoglobin A1c [79]. West et al. [80] noted increased plasma levels of the anti-inflammatory cytokine IL-10 with consumption of butyrylated high amylose maize starch. The beneficial effect of prebiotics on immune and metabolic function in the gut is thought to involve increased production of SCFAs and strengthening of gastrointestinal-associated lymphoid tissue (GALT) from fiber fermentation [81].

\section{Probiotics}

Fermented foods containing lactic acid bacteria, such as cultured milk products and yogurt, represent a source of ingestible microorganisms that may beneficially regulate intestinal health and even treat or prevent inflammatory bowel disease [82]. They are thought to accomplish this through their effects on the existing gut microbiome (studies listed in Table 6), in addition to possible induction of anti-inflammatory cytokines such as IL-10 [83]. Based on these properties, foods enriched for these modulatory microorganisms are referred to as probiotics. Several groups have reported increased total bacterial load after regular consumption of fermented milk or yogurt [84-87]. Notable increases in beneficial gut Bifidobacteria and/or Lactobacilli have also consistently been observed with several different types of probiotics [85-97]. A randomized placebo-controlled trial of 60 overweight healthy adults fed probiotics containing three strains of Bifidobacteria, four strains of Lactobacilli, and one strain of Streptococcus reported significant increases in the concentration of total aerobes, anaerobes,
Lactobacillus, Bifidobacteria, and Streptococcus compared to placebo. These subjects also had fewer total coliforms and Escherichia coli, as well as reduced triglycerides, total cholesterol, LDL-cholesterol, VLDL-cholesterol, and high-sensitivity C-reactive protein (hsCRP). HDL-cholesterol and insulin sensitivity improved after probiotic supplementation. Interestingly, the subjects with baseline low HDL, increased insulin resistance, and elevated hsCRP were noted to have significantly less total Lactobacilli and Bifidobacteria with more Escherichia coli and Bacteroides [98]. Probiotic-containing yogurt has also been shown to significantly reduce counts of the enteropathogens E. coli and Helicobacter pylori [94, 99].

Other reported health benefits from consuming fermented dairy products include alleviation of GI intolerance symptoms [86, 100-102], accelerated intestinal transit time [96], increase in total serum IgA to potentiate the humoral immune response [90, 93, 94, 103], inhibition of pathogen adhesion to intestinal mucosa [104], and decreased abdominal distention and ascites in chronic liver disease patients [99]. One study that analyzed stool from diarrhea-predominant IBS patients identified reduced abundance of Lactobacillus [105]. Interestingly, Lactobacilli and Bifidobacteria have actually been used successfully for the prophylactic prevention of traveller's diarrhea [106].

\section{Polyphenols}

Dietary polyphenols, which include catechins, flavonols, flavones, anthocyanins, proanthocyanidins and phenolic acids, are actively studied for their antioxidant properties (studies listed in Table 7). Common foods with rich polyphenol content include fruits, seeds, vegetables, tea, cocoa products, and wine [107]. Commonly enriched bacterial genera amongst studies analyzing these food sources include Bifidobacterium and Lactobacillus [56, 108-114]. Relative abundance of Bacteroides also was reported to increase in subjects consuming red wine polyphenols [110, 115, 116]. Bifidobacterium are a commonly used probiotic strain with recorded health

Table 6 Effects of probiotics on gut microbiota

\begin{tabular}{|c|c|c|c|c|c|c|c|c|c|}
\hline & $\begin{array}{l}\text { Bacterial } \\
\text { abundance }\end{array}$ & Bifidobacteria & Lactobacilli & Streptococcus & $\begin{array}{l}\text { Total aerobes/ } \\
\text { anaerobes }\end{array}$ & $\begin{array}{l}\text { Total } \\
\text { coliforms }\end{array}$ & $\begin{array}{l}\text { Helicobacter } \\
\text { pylori }\end{array}$ & $\begin{array}{l}\text { Escherichia } \\
\text { coli }\end{array}$ & References \\
\hline Probiotics & $\uparrow$ & $\uparrow$ & $\uparrow$ & $\uparrow$ & $\uparrow$ & $\downarrow$ & $\downarrow$ & $\downarrow$ & [84-98] \\
\hline
\end{tabular}

Table 7 Effects of polyphenols on gut microbiota

\begin{tabular}{llllllll}
\hline & Bifidobacteria & Lactobacilli & Bacteroides & Clostridia & Salmonella typhimurium & Staphylococcus aureus & References \\
\hline Polyphenols & $\uparrow$ & $\uparrow$ & $\downarrow$ & $\downarrow$ & $\downarrow$ & $\downarrow$ & {$[56,108-116,119-122]$} \\
\hline
\end{tabular}


benefits such as immune-modulation, cancer prevention, and inflammatory bowel disease management [63]. In terms of further health benefits, consumption of cocoaderived polyphenols has been associated with significant increases in plasma HDL and significant reductions in plasma triacylglycerol and C-reactive protein concentrations [112, 117]. Additionally, a study examining the antibacterial activity of fruit polyphenols found high sensitivity to these compounds in the enteropathogens Staphylococcus aureus and Salmonella typhimurium [118]. Moreover, reductions in pathogenic Clostridium species (C. perfringens and C. histolyticum) have been noted after consumption of fruit, seed, wine, and tea polyphenols [108, 112, 113, 119-122].

\section{Select diets}

Several popular diets, including Western, gluten-free, omnivore, vegetarian, vegan, and Mediterranean, have been studied for their ability to modulate the intestinal microbiota (Fig. 4, studies listed in Table 8). In several studies, a Western diet (high in animal protein and fat, low in fiber) led to a marked decrease in numbers of total bacteria and beneficial Bifidobacterium and Eubacterium species $[26,29,48]$. Consumption of a Western diet has also been associated with production of cancer-promoting nitrosamines $[123,124]$.

Sanz et al. had 10 healthy subjects consume a glutenfree diet for 30 days. Populations of "healthy bacteria" decreased (Bifidobacterium and Lactobacillus), while populations of potentially unhealthy bacteria increased in parallel to reductions in polysaccharide intake after beginning the diet. In particular, increases were detected in numbers of E. coli and total Enterobacteriaceae, which may include further opportunistic pathogens [125]. Bonder et al. [126] similarly investigated the influence of a short-term gluten-free diet, noting reductions in Ruminococcus bromii and Roseburia faecis with increased Victivallaceae and Clostridiaceae.

Vegan and vegetarian diets are enriched in fermentable plant-based foods. One study compared vegan and vegetarian diets to an unrestricted control diet, and found that both vegans and vegetarians had significantly lower counts of Bifidobacterium and Bacteroides species [127] $(\mathrm{p}<0.001)$. Interestingly, another study found a very modest difference in the gut microbomes of vegan versus omnivorous subjects [128]. The discrepancy between the two studies may be due to different methodologies for microbiome profiling (culture- vs sequencing-based), different control group diets, and/or host genetics. Future studies with careful experimental design will be needed to provide more insight into the differential effects of vegan and vegetarian diets on the gut microbiome.

Across the spectrum, the Mediterranean diet is highly regarded as a healthy balanced diet. It is distinguished by a beneficial fatty acid profile that is rich in both monounsaturated and polyunsaturated fatty acids, high levels of polyphenols and other antioxidants, high intake of fiber and other low glycemic carbohydrates, and relatively greater vegetable than animal protein intake. Specifically, olive oil, assorted fruits, vegetables, cereals, legumes, and nuts; moderate consumption of fish, poultry, and red wine; and a lower intake of dairy products, red meat, processed meat and sweets characterize the traditional Mediterranean diet [129]. De Filippis et al. investigated

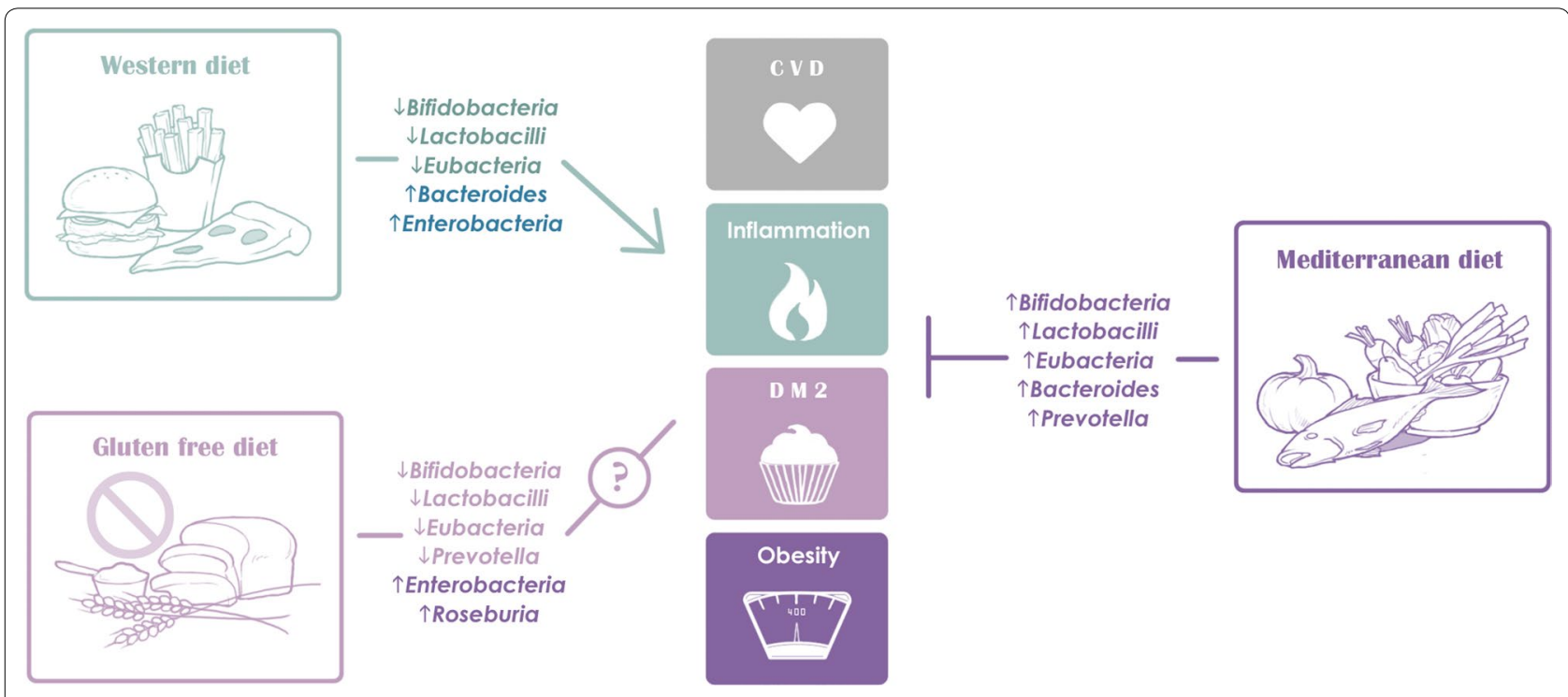

Fig. 4 Impact of popular diets on intestinal microbiota and cardiometabolic disease. CVD cardiovascular disease, DM2 type 2 diabetes mellitus 
Table 8 Effects of special diets on gut microbiota

\begin{tabular}{|c|c|c|c|c|c|c|c|c|c|c|}
\hline Diet & $\begin{array}{l}\text { Food constitu- } \\
\text { ents }\end{array}$ & $\begin{array}{l}\text { Total } \\
\text { bacteria }\end{array}$ & Bifidobacteria & Lactobacilli & Prevotella & Eubacteria & $\begin{array}{l}\text { Rose- } \\
\text { buria }\end{array}$ & $\begin{array}{l}\text { Bacte- } \\
\text { roides }\end{array}$ & Enterobacteria & References \\
\hline Western & $\begin{array}{l}\text { High animal fat/ } \\
\text { protein }\end{array}$ & $\downarrow$ & $\downarrow$ & $\downarrow$ & & $\downarrow$ & & $\uparrow$ & $\uparrow$ & {$[26,29,48]$} \\
\hline $\begin{array}{l}\text { Mediter- } \\
\text { ranean }\end{array}$ & $\begin{array}{l}\text { High fiber/antioxi- } \\
\text { dants/UFA low } \\
\text { red meat }\end{array}$ & $\uparrow$ & $\uparrow$ & $\uparrow$ & $\uparrow$ & $\uparrow$ & $\uparrow$ & $\uparrow$ & & {$[41,129,192]$} \\
\hline $\begin{array}{l}\text { Gluten- } \\
\text { free }\end{array}$ & No gluten & $\downarrow$ & $\downarrow$ & $\downarrow$ & $\downarrow$ & $\downarrow$ & $\downarrow$ & & $\uparrow$ & $\begin{array}{l}{[125,126} \\
193-195]\end{array}$ \\
\hline
\end{tabular}

UFA unsaturated fatty acids

the potential benefits of the Mediterranean diet by comparing habitual omnivores, vegetarians, and vegans. They observed that the majority of vegans and vegetarians, but only $30 \%$ of omnivores, had high adherence to the Mediterranean diet. They detected significant associations between degree of adherence to the Mediterranean diet and increased levels of fecal SCFAs, Prevotella bacteria, and other Firmicutes. At the same time low adherence to the Mediterranean diet was associated with elevated urinary trimethylamine oxide, which is associated with increased cardiovascular risk [41]. Several other studies have shown that foods comprising the typical Mediterranean diet also improve obesity, the lipid profile, and inflammation. These changes may be mediated by dietderived increases in Lactobacillus, Bifidobacterium, and Prevotella, and decreases in Clostridium [49, 110, 114, 130-132].

\section{Discussion}

The ability to rapidly identify and quantify gut bacterial genera has helped us understand the impact of diet on host microbial composition. Studies that involve intake of a specific dietary component demonstrate how certain bacteria tend to respond to the nutrient-specific challenge. Protein, fats, digestible and non-digestible carbohydrates, probiotics, and polyphenols all induce shifts in the microbiome with secondary effects on host immunologic and metabolic markers. For instance, animal protein intake positively correlates with overall microbial diversity, increases abundance of bile-tolerant organisms such as Bacteroides, Alistipes, and Bilophila, and reduces representation of the Roseburia/E. rectale group. A high-saturated fat diet seems to increase counts of total anaerobic microflora and the relative abundance of Bacteroides and Bilophila. Human studies have not reported that a highunsaturated fat diet significantly alters the gut bacterial profile; however, mouse studies have reported increases in Actinobacteria (Bifidobacterium and Adlercreutzia), lactic acid bacteria (Lactobacillus and Streptococcus), and Verrucomicrobia (Akkermansia muciniphila). Both digestible and non-digestible carbohydrates are commonly reported in the literature to enrich Bifidobacterium and suppress Clostridia, while only non-digestible carbohydrates are noted to additionally enrich for Lactobacillus, Ruminococcus, Eubacterium rectale, and Roseburia. Lastly, both probiotics and polyphenols enhance Bifidobacterium and lactic acid bacteria, while reducing enteropathogenic Clostridia species.

\section{Maintaining a healthy gut microbiome is critical to human health}

An increasing body of evidence suggests that our gut microbiome has a profound impact on our health. In the past decade, gut microorganisms have been shown to play a role in a wide range of human diseases, including obesity, psoriasis, autism, and mood disorders [133-136]. The close relationship between diet, the gut microbiome, and health suggests that we may possibly improve our health by modulating our diet. One way in which microbiota can influence host health is by modulating host immunity. Studies in germ-free animals have demonstrated that the gut microbiome is essential for immune cell recruitment and differentiation [137]. Further investigations have revealed more specific roles for some bacterial species in mediating host immunity and immunologic diseases. In particular, the segmented filamentous bacteria have been found to promote autoimmune arthritis through an enhanced Th17 response [20,138]. On the other hand, lactic acid bacteria and Bifidobacteria are known to secrete factors that dampen inflammation by downregulating NF- $\mathrm{KB}$ dependent gene expression, IL-8 secretion, and levels of macrophage-attracting chemokines [139]. Lactic acid bacteria and Bifidobacteria have also been shown to directly downregulate $\mathrm{T}$ effector-mediated inflammatory responses while upregulating anti-inflammatory $\mathrm{T}$ regulatory cell expression in mice [140]. The exact mechanism of how these gut flora modulate immune responses is still not well understood; however, several studies suggest that microbial-derived SCFAs may be contributing via G-protein-coupled receptor and epigenetic mechanisms [141, 142]. Intestinal SCFAs have also been shown to directly increase the abundance of $\mathrm{T}$ regulatory cells in 
the gut and to protect against allergic airway inflammation [17, 143-145]. In addition, they may inhibit the transcription factor NF-kB, leading to decreased secretion of several pro-inflammatory cytokines [130]. Gut flora can also modulate host immunity through epigenetic modifications. For example, microbial-derived butyrate inhibits histone deacetylases 6 and 9, which leads to increased acetylation in the promoter of the FOXP3 gene and higher regulatory $\mathrm{T}$ cell proliferation [142]. Reduced methylation in the promoters of proinflammatory genes TLR2 and FFAR3 is correlated with reduced abundance of Faecalibacterium prausnitzii in type 2 diabetes patients [146, 147]. Clearly our gut microbiome has diverse effects on host immunity, and a balanced gut flora is critical for a healthy immune system (Table 9).

Besides immunity, gut microorganisms have also been shown to impact host metabolic health. Individuals with metabolic disorders such as obesity and diabetes have been shown to have intestinal dysbiosis in relation to healthy individuals $[148,149]$. Further characterization of the link between the gut microbiome and obesity has revealed several bacterial groups that may specifically contribute to the disease. In particular, obese individuals have a high baseline Firmicutes to Bacteroidetes ratio. In these subjects, reduction of caloric intake was noted to lower the Firmicutes to Bacteroidetes ratio [148].
Intriguingly, hosts with a gut microbiome dominated by Firmicutes have altered methylation in the promoters of genes that are linked to cardiovascular disease and obesity [150]. Additionally, Lactobacillus spp. have been shown to alleviate obesity-associated metabolic complications [151, 152]. The beneficial effects of Lactobacillus may be attributed to interactions with obesity-promoting bacteria in the gut and direct modulation of host immunity and gut barrier function [153]. Interestingly, the mucusdegrading bacteria $A$. muciniphila has also been linked to a healthy metabolic profile. Obese individuals with a higher baseline relative abundance of $A$. muciniphila tend to have greater improvements in obesity-associated metabolic parameters (insulin tolerance, plasma triglycerides and body fat distribution) after dietary intervention [154]. Interestingly, germ-free mice are more resistant to diet-induced obesity, possibly due to enhanced fatty acid metabolism in the absence of certain microflora [155]. Together, these findings demonstrate the important role of gut microbiota in maintaining host metabolic integrity (Table 10).

\section{Conclusion and future directions}

In conclusion, review of the literature suggests that diet can modify the intestinal microbiome, which in turn has a profound impact on overall health. This impact can

Table 9 Effects of dietary components on immune parameters

\begin{tabular}{|c|c|c|c|c|c|c|c|c|c|c|}
\hline & SCFA & TLR & WAT & Met Endo & LPS & CRP & IL-6 & IL-10 & $\lg A$ & References \\
\hline Prebiotics & $\uparrow$ & & & & $\downarrow$ & & $\downarrow$ & $\uparrow$ & & {$[67,78-81,120]$} \\
\hline Probiotics & $\uparrow$ & & & & & $\downarrow$ & & $\uparrow$ & $\uparrow$ & {$[83,88,97-99,103]$} \\
\hline Polyphenols & & & & & & $\downarrow$ & & & $\uparrow$ & {$[115,117,122]$} \\
\hline Unsaturated fat & & $\downarrow$ & $\downarrow$ & $\downarrow$ & $\downarrow$ & & & & & {$[50,120]$} \\
\hline Saturated fat & & $\uparrow$ & $\uparrow$ & $\uparrow$ & $\uparrow$ & & & & & {$[37,52,53,58]$} \\
\hline Animal protein & $\downarrow$ & & & & & & & & & {$[39-41]$} \\
\hline Pea protein & $\uparrow$ & & & & & & & & & [31] \\
\hline
\end{tabular}

SCFA short chain fatty acids, TLR toll-like receptor activation, WAT white adipose tissue inflammation, Met Endo metabolic endotoxemia, LPS lipopolysaccharide levels, CRP C-reactive protein, IL-6 interleukin-6, IL-10 interleukin-10, IgA immunoglobulin A

Table 10 Effects of dietary components on metabolic parameters

\begin{tabular}{|c|c|c|c|c|c|c|c|}
\hline & Total chol & LDL-chol & HDL-chol & Plasma TG & Insulin sensitivity & IGF-1 production & References \\
\hline Prebiotics & $\downarrow$ & $\downarrow$ & & $\downarrow$ & $\uparrow$ & & {$[73,83,84]$} \\
\hline Probiotics & $\downarrow$ & $\downarrow$ & $\uparrow$ & $\downarrow$ & $\uparrow$ & & {$[104]$} \\
\hline Polyphenols & & & $\uparrow$ & $\downarrow$ & & & {$[110,117,122]$} \\
\hline Unsaturated fat & $\downarrow$ & $\downarrow$ & & & & & {$[41]$} \\
\hline Saturated fat & & & & & $\downarrow$ & & {$[51-53]$} \\
\hline Animal protein & & & & & & $\uparrow$ & [42] \\
\hline Artificial sweeteners & & & & & $\downarrow$ & & [59] \\
\hline
\end{tabular}

Chol cholesterol, LDL low-density lipoprotein, HDL high-density lipoprotein, TG triglycerides, IGF-1 insulin-like growth factor-1 
be beneficial or detrimental, depending on the relative identity and abundance of constituent bacterial populations. For example, it has been shown that a high-fat diet adversely reduces $A$. muciniphila and Lactobacillus, which are both associated with healthy metabolic states [53]. This observation provides a good example of how dietary intervention might potentially be used to manage complex diseases, such as obesity and diabetes. Furthermore, advances in microbiome research have suggested novel therapeutic possibilities for diseases that have traditionally been difficult to treat. For example, the fecal microbiota transplant has been used successfully to manage several different conditions, including ulcerative colitis, Clostridium difficile-associated colitis, irritable bowel syndrome, and even obesity [156-160]. It is possible that dermatologic conditions, including psoriasis and atopic dermatitis, may also be observed to benefit from re-engineering the gut microbiota. Recent advances in microbiome research offer exciting new tools to possibly enhance human health. Most of the studies reviewed in this manuscript profiled the microbiome using $16 \mathrm{~S}$ rRNA amplicon sequencing, which utilizes the hypervariable regions of the bacterial 16S rRNA gene to identify bacteria present in biological samples. $16 \mathrm{~S}$ rRNA sequencing is the most commonly used method by medical researchers to study microbial composition, due to its low cost and relatively easy workflow for sample preparation and bioinformatic analyses. However, 16S rRNA amplicon sequencing primarily provides information about microbial identity and not function. In order to investigate the microbiome's functions, many researchers have turned to a shotgun metagenomic approach in which the whole bacterial genome is sequenced. Despite a higher cost and more complicated bioinformatics requirement, shotgun metagenomics provides information about both microbial identity and gene composition. Knowing which genes are encoded by the bacteria present in a sample allows researchers to better understand their roles in human health. With reducing costs of next generation sequencing, improved sample preparation protocols, and more bioinformatic tools available for metagenomic analysis, this technique will be a powerful tool to study microbiome functionality. Performing meta-analyses to correlate the microbiome with host genomes, transcriptomes, and immunophenotypes represents another exciting avenue for investigating human and bacterial interactions.

Precision medicine is another attractive, novel therapeutic approach for many diseases with strong genetic associations. It is important to note that the host genotype also plays a role in shaping the microbiome, and that this host-microbe interaction is crucial for maintaining human health [161]. Therefore, a better understanding of the interplay between genes, phenotypes, and the microbiome will provide important insights into the utility of precision medicine.

The observation that diet can modulate host-microbe interactions heralds a promising future therapeutic approach. Already, the gut microbiome has been found to influence the response to cancer immunotherapy [162, 163]. Indeed, personalized nutrition is an emerging concept that utilizes a machine-learning algorithm to predict metabolic responses to meals $[164,165]$. This tool has broad implications for individualized patient care through dietary modification. While this and other technology is in the process of being refined and validated, further research using large, long-term clinical trials to evaluate a greater variety of food components would be helpful in making specific dietary recommendations to patients.

\section{Abbreviations}

AOS: arabinooligosaccharides; FOS: fructooligosaccharides; GALT: gutassociated lymphoid tissue; GOS: galactooligosaccharides; HDL: high-density lipoprotein; hsCRP: high-sensitivity C-reactive protein; IBD: inflammatory bowel disease; IBS: irritable bowel syndrome; IGF: insulin-like growth factor-1; LDL: low-density lipoprotein; MAC: microbiota accessible carbohydrate; TLR: toll-like receptor; TMAO: trimethylamine-N-oxide; VLDL: very low-density lipoprotein; XOS: xylooligosaccharides.

\section{Authors' contributions}

WL and TB conceived and supervised the work. RKS, HC, DY, KL, DU, KW, MA, $\mathrm{BF}, \mathrm{MN}$, and TZ performed data acquisition. RKS, $\mathrm{HC}$, and DY performed data analysis and wrote the manuscript. All named authors meet the International Committee of Medical Journal Editors (ICMJE) criteria for authorship for this manuscript, take responsibility for the integrity of the work as a whole, and have given final approval for the version to be published. All authors read and approved the final manuscript.

\section{Author details \\ 1 University of California, Los Angeles, David Geffen School of Medicine at UCLA, Los Angeles, CA 90095, USA. ${ }^{2}$ Department of Dermatology, University of Califor- nia, San Francisco, 2340 Sutter St. Room N431, Box 0808, San Francisco, CA 94115, USA. ${ }^{3}$ University of California, Irvine, School of Medicine, Irvine, CA 92697, USA. \\ ${ }^{4}$ University of Vermont College of Medicine, Burlington, VT 05405, USA. ${ }^{5}$ Univer- sity of Southern California Keck School of Medicine, Los Angeles, CA 90033, USA.}

\section{Acknowledgements}

We are grateful to the Dinsmore family for their support of this project.

\section{Competing interests}

Dr. Wilson Liao serves as a research investigator for Abbvie, Janssen, Pfizer, and Novartis. Dr. Tina Bhutani is an advisor for Cutanea and conducts research for Abbvie, Janssen, and Merck. Dr. Liao and Dr. Bhutani have no stocks, employment or board memberships with any pharmaceutical company. The remaining authors have nothing to disclose.

\section{Availability of data and materials}

The data supporting the conclusions of this article are included within the article.

\section{Consent for publication}

This article does not contain any individual person's data in any form.

\section{Ethics approval and consent to participate}

This article does not involve any new studies of human or animal subjects performed by any of the authors. 


\section{Funding}

Dr. Wilson Liao is supported in part by grants from the National Institutes of Health (R01AR065174, U01Al119125).

\section{Publisher's Note}

Springer Nature remains neutral with regard to jurisdictional claims in published maps and institutional affiliations.

Received: 30 September 2016 Accepted: 21 March 2017 Published online: 08 April 2017

\section{References}

1. Gill SR, Pop M, DeBoy RT, Eckburg PB, Turnbaugh PJ, Samuel BS, et al. Metagenomic Analysis of the human distal gut microbiome. Science. 2006;312:1355-9. http://www.sciencemag.org/cgi/doi/10.1126/ science.1124234.

2. Flint HJ, Duncan SH, Scott KP, Louis P. Interactions and competition within the microbial community of the human colon: links between diet and health. Environ Microbiol. 2007;9:1101-11.

3. Walker AW, Ince J, Duncan SH, Webster LM, Holtrop G, Ze X, et al. Dominant and diet-responsive groups of bacteria within the human colonic microbiota. ISME J. 2011:5:220-30.

4. Arumugam M, Raes J, Pelletier E, Le Paslier D, Yamada T, Mende DR, et al. Enterotypes of the human gut microbiome. Nature. 2011;473:174-80. http://www.nature.com/doifinder/10.1038/nature09944.

5. Kurokawa K, Itoh T, Kuwahara T, Oshima K, Toh H, Toyoda A, et al. Comparative metagenomics revealed commonly enriched gene sets in human gut microbiomes. DNA Res. 2007;14:169-81.

6. Walter J, Ley R. The human gut microbiome: ecology and recent evolutionary changes. Annu Rev Microbiol. 2011;65:411-29.

7. Bäckhed F, Ley RE, Sonnenburg JL, Peterson DA, Gordon Jl. Host-bacterial mutualism in the human intestine. Science. 2005;307:1915-20.

8. Topping DL, Clifton PM. Short-chain fatty acids and human colonic function: roles of resistant starch and nonstarch polysaccharides. Physiol Rev. 2001:81:1031-64.

9. Lundin A, Bok CM, Aronsson L, Björkholm B, Gustafsson JA, Pott S, et al. Gut flora, toll-like receptors and nuclear receptors: a tripartite communication that tunes innate immunity in large intestine. Cell Microbiol. 2008;10:1093-103.

10. Lee YK, Mazmanian SK. Has the microbiota played a critical role in the evolution of the adaptive immune system? Science. 2010;330:1768-73. http://www.sciencemag.org/cgi/doi/10.1126/science.1195568.

11. Belkaid $Y$, Hand TW. Role of the microbiota in immunity and inflammation. Cell. 2014;157:121-41. http://linkinghub.elsevier.com/retrieve/pii/ S0092867414003456.

12. Noverr MC, Huffnagle GB. Does the microbiota regulate immune responses outside the gut? Trends Microbiol. 2004;12:562-8.

13. David LA, Maurice CF, Carmody RN, Gootenberg DB, Button JE, Wolfe $\mathrm{BE}$, et al. Diet rapidly and reproducibly alters the human gut microbiome. Nature. 2014;505:559-63.

14. Voigt RM, Forsyth CB, Green SJ, Mutlu E, Engen P, Vitaterna MH, et al. Circadian disorganization alters intestinal microbiota. PLoS ONE. 2014;9:e97500.

15. Earley ZM, Akhtar S, Green SJ, Naqib A, Khan O, Cannon AR, et al. Burn Injury alters the intestinal microbiome and increases gut permeability and bacterial translocation. PLoS ONE. 2015;10:e0129996. http://dx.plos. org/10.1371/journal.pone.0129996.

16. Lucas López R, Grande Burgos MJ, Gálvez A, Pérez Pulido R. The human gastrointestinal tract and oral microbiota in inflammatory bowel disease: a state of the science review. APMIS. 2017. http://onlinelibrary. wiley.com/doi/10.1111/apm.12609/abstract.

17. Schäffler H, Herlemann DP, Alberts C, Kaschitzki A, Bodammer P, Bannert K, et al. Mucosa-attached bacterial community in Crohn's Disease coheres with the clinical disease activity index. Environ Microbiol Rep. 2016;8:614-21.

18. Smith PM, Howitt MR, Panikov N, Michaud M, Gallini CA, Bohlooly-Y M, et al. The microbial metabolites, short-chain fatty acids, regulate colonic treg cell homeostasis. Science. 2013;341:569-73.
19. Greenblum S, Turnbaugh PJ, Borenstein E. Metagenomic systems biology of the human gut microbiome reveals topological shifts associated with obesity and inflammatory bowel disease. Proc Natl Acad Sci. 2012;109:594-9. http://www.pnas.org/cgi/doi/10.1073/pnas.1116053109.

20. Schicho R, Marsche G, Storr M. Cardiovascular complications in inflammatory bowel disease. Curr Drug Targets. 2015;16:181-8.

21. Wu HJ, Ivanov II, Darce J, Hattori K, Shima T, Umesaki Y, et al. Gut-residing segmented filamentous bacteria drive autoimmune arthritis via T helper 17 cells. Immunity. 2010;32:815-27.

22. Qin J, Li Y, Cai Z, Li S, Zhu J, Zhang F, et al. A metagenome-wide association study of gut microbiota in type 2 diabetes. Nature. 2012:490:55-60.

23. Turnbaugh PJ, Ley RE, Mahowald MA, Magrini V, Mardis ER, Gordon Jl. An obesity-associated gut microbiome with increased capacity for energy harvest. Nature. 2006;444:1027-31.

24. Koeth RA, Wang Z, Levison BS, Buffa JA, Org E, Sheehy BT, et al. Intestinal microbiota metabolism of L-carnitine, a nutrient in red meat, promotes atherosclerosis. Nat Med. 2013;19:576-85.

25. Pistollato $F$, et al. Role of gut microbiota and nutrients in amyloid formation and pathogenesis of Alzheimer disease. Nutr Rev. 2016;74:624-34.

26. Wu GD, Chen J, Hoffmann C, Bittinger K, Chen YY, Keilbaugh SA, et al. Linking long-term dietary patterns with gut microbial enterotypes. Science. 2011:334:105-8.

27. Hentges DJ, Maier BR, Burton GC, Flynn MA, Tsutakawa RK. Effect of a high-beef diet on the fecal bacterial flora of humans. Cancer Res. 1977;37:568-71.

28. Clarke SF, Murphy EF, O'Sullivan O, Lucey AJ, Humphreys M, Hogan A, et al. Exercise and associated dietary extremes impact on gut microbial diversity. Gut. 2014;63:1913-20.

29. Reddy BS, Weisburger JH, Wynder EL. Effects of high risk and low risk diets for colon carcinogenesis on fecal microflora and steroids in man. J Nutr. 1975:105:878-84.

30. Cotillard A, Kennedy SP, Kong LC, Prifti E, Pons N, Le Chatelier E, et al. Dietary intervention impact on gut microbial gene richness. Nature. 2013;500:585-8

31. Świątecka D, Dominika Ś, Narbad A, Arjan N, Ridgway KP, Karyn RP, et al. The study on the impact of glycated pea proteins on human intestinal bacteria. Int J Food Microbiol. 2011;145:267-72.

32. Meddah AT, Yazourh A, Desmet I, Risbourg B, Verstraete W, Romond MB. The regulatory effects of whey retentate from bifidobacteria fermented milk on the microbiota of the simulator of the human intestinal microbial ecosystem (SHIME). J Appl Microbiol. 2001;91:1110-7.

33. Romond MB, Ais A, Guillemot F, Bounouader R, Cortot A, Romond C. Cell-free whey from milk fermented with Bifidobacterium breve $\mathrm{C} 50$ used to modify the colonic microflora of healthy subjects. J Dairy Sci. 1998;81:1229-35.

34. Kim CH, Park J, Kim M. Gut microbiota-derived short-chain fatty acids, T cells, and inflammation. Immune Netw. 2014;14:277. http://synapse koreamed.org/DOlx.php?id=10.4110/in.2014.14.6.277.

35. De Filippo C, Cavalieri D, Di Paola M, Ramazzotti M, Poullet JB, Massart S, et al. Impact of diet in shaping gut microbiota revealed by a comparative study in children from Europe and rural Africa. Proc Natl Acad Sci USA. 2010;107:14691-6.

36. Russell WR, Gratz SW, Duncan SH, Holtrop G, Ince J, Scobbie L, et al. High-protein, reduced-carbohydrate weight-loss diets promote metabolite profiles likely to be detrimental to colonic health. Am J Clin Nutr. 2011;93:1062-72.

37. Kang S, Denman SE, Morrison M, Yu Z, Dore J, Leclerc M, et al. Dysbiosis of fecal microbiota in Crohn's disease patients as revealed by a custom phylogenetic microarray. Inflamm Bowel Dis. 2010;16:2034-42. http:// content.wkhealth.com/linkback/openurl?sid=WKPTLP:landingpage \&an=00054725-201012000-00009.

38. Eeckhaut V, Machiels K, Perrier C, Romero C, Maes S, Flahou B, et al. Butyricicoccus pullicaecorum in inflammatory bowel disease. Gut. 2013;62:1745-52. http://gut.bmj.com/cgi/doi/10.1136/ gutjnl-2012-303611.

39. Machiels K, Joossens M, Sabino J, De Preter V, Arijs I, Eeckhaut V, et al. A decrease of the butyrate-producing species Roseburia hominis and Faecalibacterium prausnitzii defines dysbiosis in patients with ulcerative colitis. Gut. 2014;63:1275-83. http://gut.bmj.com/cgi/doi/10.1136/ gutjnl-2013-304833. 
40. Jantchou P, Morois S, Clavel-Chapelon F, Boutron-Ruault M-C, Carbonnel F. Animal protein intake and risk of inflammatory bowel disease: The E3N prospective study. Am J Gastroenterol. 2010;105:2195-201.

41. DeFilippis F, Pellegrini N, Vannini L, Jeffery IB, La Storia A, Laghi L, et al. High-level adherence to a Mediterranean diet beneficially impacts the gut microbiota and associated metabolome. Gut. 2015:gutjnl-2015. http://gut.bmj.com/lookup/doi/10.1136/gutjnl-2015-309957.

42. Levine ME, Suarez JA, Brandhorst S, Balasubramanian P, Cheng CW, Madia $F$, et al. Low protein intake is associated with a major reduction in IGF-1, cancer, and overall mortality in the 65 and younger but not older population. Cell Metab. 2014;19:407-17.

43. Spady DK, Woollett LA, Dietschy JM. Regulation of plasma LDLcholesterol levels by dietary cholesterol and fatty acids. Annu Rev Nutr. 1993;13:355-81.

44. Stamler J, Daviglus ML, Garside DB, Dyer AR, Greenland P, Neaton JD. Relationship of baseline serum cholesterol levels in 3 large cohorts of younger men to long-term coronary, cardiovascular, and all-cause mortality and to longevity. JAMA. 2000;284:311-8.

45. Kris-Etherton PM. Fish consumption, fish oil, omega-3 fatty acids, and cardiovascular disease. Circulation. 2002;106:2747-57. http://circ. ahajournals.org/cgi/doi/10.1161/01.CIR.0000038493.65177.94.

46. Simopoulos AP. Omega-3 fatty acids in inflammation and autoimmune diseases. J Am Coll Nutr. 2002;21:495-505.

47. Dietary fats: total fat and fatty acids in: dietary reference intakes for energy, carbohydrate, fiber, fat, fatty acids, cholesterol, protein, and amino acids (macronutrients). Washington, DC: National Academies Press; 2002. p. 335-432.

48. Drasar BS, Crowther JS, Goddard P, Hawksworth G, Hill MJ, Peach $S$, et al. The relation between diet and the gut microflora in man. Proc Nutr Soc. 2007;32:49-52. http://www.journals.cambridge.org/ abstract_S0029665173000170.

49. Fava F, Gitau R, Griffin BA, Gibson GR, Tuohy KM, Lovegrove JA. The type and quantity of dietary fat and carbohydrate alter faecal microbiome and short-chain fatty acid excretion in a metabolic syndrome "at-risk" population. Int J Obes (Lond). 2013;37:216-23.

50. Urwin HJ, Miles EA, Noakes PS, Kremmyda LS, Vlachava M, Diaper ND, et al. Effect of salmon consumption during pregnancy on maternal and infant faecal microbiota, secretory IgA and calprotectin. Br J Nutr. 2014;111:773-84.

51. Lecomte V, Kaakoush NO, Maloney CA, Raipuria M, Huinao KD, Mitchell HM, et al. Changes in gut microbiota in rats fed a high fat diet correlate with obesity-associated metabolic parameters. PLoS ONE. 2015;10:e0126931. http://dx.plos.org/10.1371/journal.pone.0126931.

52. Cani PD, Bibiloni R, Knauf C, Waget A, Neyrinck AM, Delzenne NM, et al. Changes in gut microbiota control metabolic endotoxemia-induced inflammation in high-fat diet-induced obesity and diabetes in mice. Diabetes. 2008;57:1470-81.

53. Caesar R, Tremaroli V, Kovatcheva-Datchary P, Cani PD, Bäckhed F. Crosstalk between gut microbiota and dietary lipids aggravates WAT inflammation through TLR signaling. Cell Metab. 2015;22:658-68. http://linkinghub.elsevier.com/retrieve/pii/S1550413115003897.

54. Saltiel AR. Insulin signaling in the control of glucose and lipid homeostasis. Handb Exp Pharmacol. 2016.

55. Parvin S. Nutritional analysis of date fruits (Phoenix dactylifera L.) in perspective of Bangladesh. Am J Life Sci. 2015;3:274. http://www. sciencepublishinggroup.com/journal/paperinfo.aspx?journalid=118\&d oi=10.11648/j.ajls.20150304.14.

56. Eid N, Enani S, Walton G, Corona G, Costabile A, Gibson G, et al. The impact of date palm fruits and their component polyphenols, on gut microbial ecology, bacterial metabolites and colon cancer cell proliferation. J Nutr Sci. 2014;3:e46. http://www.journals.cambridge.org/ abstract_S2048679014000160.

57. Jeffery I, O'Toole P. Diet-microbiota interactions and their implications for healthy living. Nutrients. 2013;5:234-52. http://www.mdpi. com/2072-6643/5/1/234/.

58. Francavilla R, Calasso M, Calace L, Siragusa S, Ndagijimana M, Vernocchi $P$, et al. Effect of lactose on gut microbiota and metabolome of infants with cow's milk allergy. Pediatr Allergy Immunol. 2012;23:420-7.
59. Suez J, Korem T, Zeevi D, Zilberman-Schapira G, Thaiss CA, Maza O, et al. Artificial sweeteners induce glucose intolerance by altering the gut microbiota. Nature. 2014;514:181-6.

60. Lozupone CA, Stombaugh Jl, Gordon Jl, Jansson JK, Knight R. Diversity, stability and resilience of the human gut microbiota. Nature. 2012;489:220-30. http://www.nature.com/doifinder/10.1038/ nature11550.

61. Sonnenburg ED, Sonnenburg JL. Starving our microbial self: the deleterious consequences of a diet deficient in microbiota-accessible carbohydrates. Cell Metab. 2014;20:779-86. http://linkinghub.elsevier. com/retrieve/pii/S1550413114003118.

62. de Vrese M, Schrezenmeir J. Probiotics, prebiotics, and synbiotics. Adv Biochem Eng Biotechnol. 2008;111:1-66.

63. Pandey KR, Naik SR, Vakil BV. Probiotics, prebiotics and synbiotics-a review. J Food Sci Technol. 2015;52:7577-87.

64. Halmos EP, Christophersen CT, Bird AR, Shepherd SJ, Gibson PR, Muir $J G$. Diets that differ in their FODMAP content alter the colonic luminal microenvironment. Gut. 2015;64:93-100.

65. Costabile A, Klinder A, Fava F, Napolitano A, Fogliano V, Leonard C, et al. Whole-grain wheat breakfast cereal has a prebiotic effect on the human gut microbiota: a double-blind, placebo-controlled, crossover study. Br J Nutr. 2008;99:110-20.

66. Carvalho-Wells AL, Helmolz K, Nodet C, Molzer C, Leonard C, McKevith $B$, et al. Determination of the in vivo prebiotic potential of a maizebased whole grain breakfast cereal: a human feeding study. Br J Nutr. 2010;104:1353-6.

67. Keim NL, Martin RJ. Dietary whole grain-microbiota interactions: insights into mechanisms for human health. Adv Nutr. 2014;5:556-7.

68. Leitch ECM, Walker AW, Duncan SH, Holtrop G, Flint HJ. Selective colonization of insoluble substrates by human faecal bacteria. Environ Microbiol. 2007;9:667-79.

69. Liu Z, Lin X, Huang G, Zhang W, Rao P, Ni L. Prebiotic effects of almonds and almond skins on intestinal microbiota in healthy adult humans. Anaerobe. 2014;26:1-6.

70. Gori A, Rizzardini G, Van't Land B, Amor KB, van Schaik J, Torti C, et al. Specific prebiotics modulate gut microbiota and immune activation in HAART-naive HIV-infected adults: results of the "COPA" pilot randomized trial. Mucosal Immunol. 2011;4:554-63.

71. Costabile A, Fava F, Röytiö H, Forssten SD, Olli K, Klievink J, et al. Impact of polydextrose on the faecal microbiota: a double-blind, crossover, placebo-controlled feeding study in healthy human subjects. Br J Nutr. 2012;108:471-81.

72. Kedia G, Vázquez JA, Charalampopoulos D, Pandiella SS. In vitro fermentation of oat bran obtained by debranning with a mixed culture of human fecal bacteria. Curr Microbiol. 2009;58:338-42.

73. Yu ZT, Liu B, Mukherjee P, Newburg DS. Trametes versicolor extract modifies human fecal microbiota composition in vitro. Plant Foods Hum Nutr. 2013;68:107-12.

74. Flickinger EA, Hatch TF, Wofford RC, Grieshop CM, Murray SM, Fahey GC. In vitro fermentation properties of selected fructooligosaccharide-containing vegetables and in vivo colonic microbial populations are affected by the diets of healthy human infants. J Nutr. 2002;132:2188-94.

75. Kapiki A, Costalos C, Oikonomidou C, Triantafyllidou A, Loukatou E, Pertrohilou $\mathrm{V}$. The effect of a fructo-oligosaccharide supplemented formula on gut flora of preterm infants. Early Hum Dev. 2007;83:335-9.

76. François IEJA, Lescroart O, Veraverbeke WS, Marzorati M, Possemiers S, Hamer $\mathrm{H}$, et al. Effects of wheat bran extract containing arabinoxylan oligosaccharides on gastrointestinal parameters in healthy preadolescent children. J Pediatr Gastroenterol Nutr. 2014;58:647-53.

77. Chen HM, Yu YN, Wang JL, Lin YW, Kong X, Yang CQ, et al. Decreased dietary fiber intake and structural alteration of gut microbiota in patients with advanced colorectal adenoma. Am J Clin Nutr. 2013;97:1044-52.

78. Martínez I, Lattimer JM, Hubach KL, Case JA, Yang J, Weber CG, et al. Gut microbiome composition is linked to whole grain-induced immunological improvements. ISME J. 2013;7:269-80.

79. Kim MS, Hwang SS, Park EJ, Bae JW. Strict vegetarian diet improves the risk factors associated with metabolic diseases by modulating gut microbiota and reducing intestinal inflammation. Environ Microbiol Rep. 2013;5:765-75. 
80. West NP, Christophersen CT, Pyne DB, Cripps AW, Conlon MA, Topping $\mathrm{DL}$, et al. Butyrylated starch increases colonic butyrate concentration but has limited effects on immunity in healthy physically active individuals. Exerc Immunol Rev. 2013;19:102-19.

81. Schley PD, Field CJ. The immune-enhancing effects of dietary fibres and prebiotics. Br J Nutr. 2002;87(Suppl 2):S221-30.

82. Shen J, Zuo ZX, Mao AP. Effect of probiotics on inducing remission and maintaining therapy in ulcerative colitis, Crohn's disease, and pouchitis. Inflamm Bowel Dis. 2014;20:21-35. http://content. wkhealth.com/linkback/openurl?sid=WKPTLP:landingpage \&an $=00054725-201401000-00004$

83. Foligné B, Parayre S, Cheddani R, Famelart MH, Madec MN, Plé C, et al. Immunomodulation properties of multi-species fermented milks. Food Microbiol. 2016;53:60-9.

84. Matsumoto K, Takada T, Shimizu K, Moriyama K, Kawakami K, Hirano $K$, et al. Effects of a probiotic fermented milk beverage containing Lactobacillus casei strain Shirota on defecation frequency, intestinal microbiota, and the intestinal environment of healthy individuals with soft stools. J Biosci Bioeng. 2010;110:547-52.

85. He T, Priebe MG, Zhong Y, Huang C, Harmsen HJM, Raangs GC, et al. Effects of yogurt and bifidobacteria supplementation on the colonic microbiota in lactose-intolerant subjects. J Appl Microbiol. 2008;104:595-604

86. Zhong Y, Huang CY, He T, Harmsen HMJ. Effect of probiotics and yogurt on colonic microflora in subjects with lactose intolerance. Wei Sheng Yan Jiu. 2006:35:587-91.

87. Goossens DAM, Jonkers DMAE, Russel MGVM, Stobberingh EE, Stockbrügger RW. The effect of a probiotic drink with Lactobacillus plantarum 299v on the bacterial composition in faeces and mucosal biopsies of rectum and ascending colon. Aliment Pharmacol Ther. 2006:23:255-63.

88. Wang S, Zhu H, Lu C, Kang Z, Luo Y, Feng L, et al. Fermented milk supplemented with probiotics and prebiotics can effectively alter the intestinal microbiota and immunity of host animals. J. Dairy Sci. 2012;95:4813-22.

89. Sairanen U, Piirainen L, Gråsten S, Tompuri T, Mättö J, Saarela M, et al. The effect of probiotic fermented milk and inulin on the functions and microecology of the intestine. J Dairy Res. 2007;74:367-73.

90. TormoCarnicer R, Infante Piña D, Roselló Mayans E, Bartolomé Comas R. Intake of fermented milk containing Lactobacillus casei DN-114 001 and its effect on gut flora. An Pediatr (Barc). 2006;65:448-53.

91. Spanhaak S, Havenaar R, Schaafsma G. The effect of consumption of milk fermented by Lactobacillus casei strain Shirota on the intestinal microflora and immune parameters in humans. Eur J Clin Nutr. 1998;52:899-907.

92. Bouhnik Y, Flourie B, Andrieux C, Bisetti N, Briet F, Rambaud JC. Effects of Bifidobacterium sp. fermented milk ingested with or without inulin on colonic bifidobacteria and enzymatic activities in healthy humans. Eur J Clin Nutr. 1996;50:269-73.

93. Link-Amster H, Rochat F, Saudan KY, Mignot O, Aeschlimann JM. Modulation of a specific humoral immune response and changes in intestinal flora mediated through fermented milk intake. FEMS Immunol Med Microbiol. 1994;10:55-63.

94. Yang YJ, Sheu BS. Probiotics-containing yogurts suppress Helicobacter pylori load and modify immune response and intestinal microbiota in the Helicobacter pylori-infected children. Helicobacter. 2012;17:297-304.

95. García-Albiach R, PozuelodeFelipe MJ, José M, deFelipe P, Angulo S, Morosini Ml, et al. Molecular analysis of yogurt containing Lactobacillus delbrueckii subsp. bulgaricus and Streptococcus thermophilus in human intestinal microbiota. Am J Clin Nutr. 2008;87:91-6.

96. Bartram HP, Scheppach W, Gerlach S, Ruckdeschel G, Kelber E, Kasper $H$. Does yogurt enriched with Bifidobacterium longum affect colonic microbiology and fecal metabolites in healthy subjects? Am J Clin Nutr. 1994:59:428-32.

97. Inoguchi S, Ohashi Y, Narai-Kanayama A, Aso K, Nakagaki T, Fujisawa T. Effects of non-fermented and fermented soybean milk intake on faecal microbiota and faecal metabolites in humans. Int J Food Sci Nutr. 2012:63:402-10

98. Rajkumar H, Mahmood N, Kumar M, Varikuti SR, Challa HR, Myakala SP. Effect of probiotic (VSL\#3) and omega-3 on lipid profile, insulin sensitivity, inflammatory markers, and gut colonization in overweight adults: a randomized, controlled trial. Med Inflamm. 2014;2014:348959.

99. Liu JE, Zhang Y, Zhang J, Dong PL, Chen M, Duan ZP. Probiotic yogurt effects on intestinal flora of patients with chronic liver disease. Nurs Res. 2010;59:426-32.

100. Yoon H, Park YS, Lee DH, Seo J-G, Shin CM, Kim N. Effect of administering a multi-species probiotic mixture on the changes in fecal microbiota and symptoms of irritable bowel syndrome: a randomized, doubleblind, placebo-controlled trial. J Clin Biochem Nutr. 2015;57:129-34.

101. del Campo R, Garriga M, PérezAragón A, Guallarte P, Lamas A, Máiz L, et al. Improvement of digestive health and reduction in proteobacterial populations in the gut microbiota of cystic fibrosis patients using a Lactobacillus reuteri probiotic preparation: a double blind prospective study. J Cyst Fibros. 2014;13:716-22.

102. Kwak DS, Jun DW, Seo JG, Chung WS, Park SE, Lee KN, et al. Short-term probiotic therapy alleviates small intestinal bacterial overgrowth, but does not improve intestinal permeability in chronic liver disease. Eur J Gastroenterol Hepatol. 2014:26:1353-9.

103. Akatsu H, Iwabuchi N, Xiao J-Z, Matsuyama Z, Kurihara R, Okuda K, et al. Clinical effects of probiotic Bifidobacterium longum BB536 on immune function and intestinal microbiota in elderly patients receiving enteral tube feeding. JPEN J Parenter Enteral Nutr. 2013;37:631-40.

104. Collado MC, Surono IS, Meriluoto J, Salminen S. Potential probiotic characteristics of Lactobacillus and Enterococcus strains isolated from traditional dadih fermented milk against pathogen intestinal colonization. J Food Prot. 2007:70:700-5.

105. Malinen E, RinttiläT, Kajander K, Mättö J, Kassinen A, Krogius L, et al. Analysis of the fecal microbiota of irritable bowel syndrome patients and healthy controls with real-time PCR. Am J Gastroenterol. 2005;100:373-82.

106. McFarland LV. Meta-analysis of probiotics for the prevention of traveler's diarrhea. Travel Med Infect Dis. 2007;5:97-105.

107. Pérez-Jiménez J, Neveu V, Vos F, Scalbert A. Identification of the 100 richest dietary sources of polyphenols: an application of the phenolexplorer database. Eur J Clin Nutr. 2010;64:S112-20.

108. Cuervo A, Valdés L, Salazar N, de los Reyes-Gavilán CG, Ruas-Madiedo P, Gueimonde M, et al. Pilot study of diet and microbiota: interactive associations of fibers and polyphenols with human intestinal bacteria. J Agric Food Chem. 2014;62:5330-6.

109. Vendrame S, Guglielmetti S, Riso P, Arioli S, Klimis-Zacas D, Porrini M. Six-week consumption of a wild blueberry powder drink increases bifidobacteria in the human gut. J Agric Food Chem. 2011;59:12815-20.

110. Queipo-Ortuno MI, Boto-Ordonez M, Murri M, Gomez-Zumaquero JM, Clemente-Postigo M, Estruch R, et al. Influence of red wine polyphenols and ethanol on the gut microbiota ecology and biochemical biomarkers. Am J Clin Nutr. 2012;95:1323-34.

111. Jin JS, Touyama M, Hisada T, Benno Y. Effects of green tea consumption on human fecal microbiota with special reference to Bifidobacterium species. Microbiol Immunol. 2012;56:729-39.

112. Tzounis X, Rodriguez-Mateos A, Vulevic J, Gibson GR, Kwik-Uribe C, Spencer JPE. Prebiotic evaluation of cocoa-derived flavanols in healthy humans by using a randomized, controlled, double-blind, crossover intervention study. Am J Clin Nutr. 2011;93:62-72.

113. Cueva C, Sánchez-Patán F, Monagas M, Walton GE, Gibson GR, MartínÁlvarez PJ, et al. In vitro fermentation of grape seed flavan-3-ol fractions by human faecal microbiota: changes in microbial groups and phenolic metabolites. FEMS Microbiol Ecol. 2013;83:792-805.

114. Bialonska D, Ramnani P, Kasimsetty SG, Muntha KR, Gibson GR, Ferreira D. The influence of pomegranate by-product and punicalagins on selected groups of human intestinal microbiota. Int J Food Microbiol. 2010;140:175-82.

115. Cuervo A, Hevia A, López P, Suárez A, Diaz C, Sánchez B, et al. Phenolic compounds from red wine and coffee are associated with specific intestinal microorganisms in allergic subjects. Food Funct. 2015.

116. Barroso E, VandeWiele T, Jiménez-Girón A, Muñoz-González I, Martín-Alvarez PJ, Moreno-Arribas MV, et al. Lactobacillus plantarum IFPL935 impacts colonic metabolism in a simulator of the human gut microbiota during feeding with red wine polyphenols. Appl Microbiol Biotechnol. 2014;98:6805-15.

117. Martin FPJ, Montoliu I, Nagy K, Moco S, Collino S, Guy P, et al. Specific dietary preferences are linked to differing gut microbial metabolic 
activity in response to dark chocolate intake. J Proteom Res. 2012;11:6252-63.

118. Parkar SG, Stevenson DE, Skinner MA. The potential influence of fruit polyphenols on colonic microflora and human gut health. Int J Food Microbiol. 2008;124:295-8.

119. Lee HC, Jenner AM, Low CS, Lee YK. Effect of tea phenolics and their aromatic fecal bacterial metabolites on intestinal microbiota. Res Microbiol. 2006;157:876-84

120. Druart C, Dewulf EM, Cani PD, Neyrinck AM, Thissen JP, Delzenne NM. Gut microbial metabolites of polyunsaturated fatty acids correlate with specific fecal bacteria and serum markers of metabolic syndrome in obese women. Lipids. 2014;49:397-402.

121. Sánchez-Patán F, Cueva C, Monagas M, Walton GE, Gibson MGR, Quintanilla-López JE, et al. In vitro fermentation of a red wine extract by human gut microbiota: changes in microbial groups and formation of phenolic metabolites. J Agric Food Chem. 2012;60:2136-47.

122. Tzounis X, Vulevic J, Kuhnle GGC, George T, Leonczak J, Gibson GR, et al. Flavanol monomer-induced changes to the human faecal microflora. $\mathrm{Br}$ J Nutr. 2008;99:782-92.

123. Mitsuoka T. The effect of nutrition on intestinal flora. Nahrung. 1984;28:619-25

124. Park JE, Seo JE, Lee JY, Kwon H. Distribution of seven $\mathrm{N}$-nitrosamines in food. Toxicol Res. 2015;31:279-88.

125. Sanz Y. Effects of a gluten-free diet on gut microbiota and immune function in healthy adult humans. Gut Microbes. 1:135-7.

126. Bonder MJ, Tigchelaar EF, Cai X, Trynka G, Cenit MC, Hrdlickova B, et al. The influence of a short-term gluten-free diet on the human gut microbiome. Genome Med. 2016;8:45. Available from: http://genomemedicine.biomedcentral.com/articles/10.1186/s13073-016-0295-y.

127. Wu GD, Compher C, Chen EZ, Smith SA, Shah RD, Bittinger K, et al. Comparative metabolomics in vegans and omnivores reveal constraints on diet-dependent gut microbiota metabolite production. Gut. 2014.

128. Zimmer J, Lange B, Frick J-S, Sauer H, Zimmermann K, Schwiertz A, et al. $A$ vegan or vegetarian diet substantially alters the human colonic faecal microbiota. Eur J Clin Nutr. 2012;66:53-60.

129. Lopez-Legarrea P, Fuller NR, Zulet MA, Martinez JA, Caterson ID. The influence of Mediterranean, carbohydrate and high protein diets on gut microbiota composition in the treatment of obesity and associated inflammatory state. Asia Pac J Clin Nutr. 2014;23:360-8.

130. Furet JP, Kong LC, Tap J, Poitou C, Basdevant A, Bouillot JL, et al. Differential adaptation of human gut microbiota to bariatric surgery-induced weight loss: links with metabolic and low-grade inflammation markers. Diabetes. 2010;59:3049-57.

131. Clemente-Postigo M, Queipo-Ortuno Ml, Murri M, Boto-Ordonez M, Perez-Martinez P, Andres-Lacueva C, et al. Endotoxin increase after fat overload is related to postprandial hypertriglyceridemia in morbidly obese patients. J Lipid Res. 2012;53:973-8.

132. Koloverou E, Panagiotakos DB, Pitsavos C, Chrysohoou C, Georgousopoulou EN, Grekas A, et al. Adherence to Mediterranean diet and 10-year incidence (2002-2012) of diabetes: correlations with inflammatory and oxidative stress biomarkers in the ATTICA cohort study. Diabetes Metab Res Rev. 2016;32:73-81.

133. Scher JU, Ubeda C, Artacho A, Attur M, Isaac S, Reddy SM, et al. Decreased bacterial diversity characterizes the altered gut microbiota in patients with psoriatic arthritis, resembling dysbiosis in inflammatory bowel disease. Arthritis Rheumatol. 2015;67:128-39.

134. Ridaura VK, Faith JJ, Rey FE, Cheng J, Duncan AE, Kau AL, et al. Gut Microbiota from twins discordant for obesity modulate metabolism in mice. Science. 2013;341:1241214. Available from: http://www. sciencemag.org/cgi/doi/10.1126/science.1241214.

135. Hsiao EY, McBride SW, Hsien S, Sharon G, Hyde ER, McCue T, et al. Microbiota modulate behavioral and physiological abnormalities associated with neurodevelopmental disorders. Cell. 2013;155:1451-63.

136. Mangiola F, laniro G, Franceschi F, Fagiuoli S, Gasbarrini G, Gasbarrini A. Gut microbiota in autism and mood disorders. World I Gastroenterol. 2016:22:361-8.

137. Haverson K, Rehakova Z, Sinkora J, Sver L, Bailey M. Immune development in jejunal mucosa after colonization with selected commensal gut bacteria: a study in germ-free pigs. Vet Immunol Immunopathol. 2007;119:243-53.
138. Ivanov II, Atarashi K, Manel N, Brodie EL, Shima T, Karaoz U, et al. Induction of intestinal Th17 cells by segmented filamentous bacteria. Cell. 2009:139:485-98.

139. Delcenserie V, Martel D, Lamoureux M, Amiot J, Boutin Y, Roy D. Immunomodulatory effects of probiotics in the intestinal tract. Curr Issues Mol Biol. 2008;10:37-54.

140. Kwon HK, Lee CG, So JS, Chae CS, Hwang JS, Sahoo A, et al. Generation of regulatory dendritic cells and CD4 + Foxp3 + T cells by probiotics administration suppresses immune disorders. Proc Natl Acad Sci USA. 2010;107:2159-64.

141. Andrade MER, Araújo RS, de Barros PAV, Soares ADN, Abrantes FA, Generoso S, de Vasconcelos Generoso S, et al. The role of immunomodulators on intestinal barrier homeostasis in experimental models. Clin Nutr. 2015;34:1080-7.

142. Tilg H, Moschen AR. Food, immunity, and the microbiome. Gastroenterology. 2015;148:1107-19.

143. Arpaia N, Campbell C, Fan X, Dikiy S, van der Veeken J, DeRoos P, et al. Metabolites produced by commensal bacteria promote peripheral regulatory T-cell generation. Nature. 2013;504:451-5.

144. Furusawa Y, Obata Y, Fukuda S, Endo TA, Nakato G, Takahashi D, et al. Commensal microbe-derived butyrate induces the differentiation of colonic regulatory T cells. Nature. 2013;504:446-50.

145. Trompette A, Gollwitzer ES, Yadava K, Sichelstiel AK, Sprenger N, NgomBru C, et al. Gut microbiota metabolism of dietary fiber influences allergic airway disease and hematopoiesis. Nat Med. 2014;20:159-66.

146. Remely $\mathrm{M}$, et al. Effects of short chain fatty acid producing bacteria on epigenetic regulation of FFAR3 in type 2 diabetes and obesity. Gene. 2014;537:85-92.

147. Remely $\mathrm{M}$, et al. Microbiota and epigenetic regulation of inflammatory mediators in type 2 diabetes and obesity. Benef Microbes. 2014;5:33-43.

148. Ley RE, Turnbaugh PJ, Klein S, Gordon JI. Microbial ecology: human gut microbes associated with obesity. Nature. 2006;444:1022-3.

149. Karlsson F, Tremaroli V, Nielsen J, Bäckhed F. Assessing the human gut microbiota in metabolic diseases. Diabetes. 2013;62:3341-9.

150. Kumar $\mathrm{H}$, et al. Gut microbiota as an epigenetic regulator: pilot study based on whole-genome methylation analysis. MBio. 2014;5:e0211314. http://mbio.asm.org/content/5/6/e02113-14.short.

151. Aller R, De Luis DA, Izaola O, Conde R, Gonzalez Sagrado M, Primo D, et al. Effect of a probiotic on liver aminotransferases in nonalcoholic fatty liver disease patients: a double blind randomized clinical trial. Eur Rev Med Pharmacol Sci. 2011;15:1090-5.

152. Nardone G, Compare D, Liguori E, Di Mauro V, Rocco A, Barone M, et al. Protective effects of Lactobacillus paracasei F19 in a rat model of oxidative and metabolic hepatic injury. Am J Physiol Gastrointest Liver Physiol. 2010;299:G669-76.

153. Compare D, Coccoli P, Rocco A, Nardone OM, De Maria S, Cartenì M, et al. Gut-liver axis: The impact of gut microbiota on non alcoholic fatty liver disease. Nutr Metab Cardiovasc Dis. 2012;22:471-6.

154. Dao MC, Everard A, Aron-Wisnewsky J, Sokolovska N, Prifti E, Verger EO, et al. Akkermansia muciniphila and improved metabolic health during a dietary intervention in obesity: relationship with gut microbiome richness and ecology. Gut. 2015.

155. Bäckhed F, Manchester JK, Semenkovich CF, Gordon JI. Mechanisms underlying the resistance to diet-induced obesity in germ-free mice. Proc Natl Acad Sci USA. 2007;104:979-84.

156. Tian Z, Liu J, Liao M, Li W, Zou J, Han X, et al. Beneficial effects of fecal microbiota transplantation on ulcerative colitis in mice. Dig Dis Sci. 2016.

157. Padua D, Pothoulakis C. Novel approaches to treating Clostridium difficile-associated colitis. Expert Rev Gastroenterol Hepatol. 2016;10:193-204.

158. Lee CH, Steiner T, Petrof EO, Smieja M, Roscoe D, Nematallah A, et al. Frozen vs fresh fecal microbiota transplantation and clinical resolution of diarrhea in patients with recurrent Clostridium difficile infection: a randomized clinical trial. JAMA. 2016:315:142-9.

159. Konturek PC, Haziri D, Brzozowski T, Hess T, Heyman S, Kwiecien S, et al. Emerging role of fecal microbiota therapy in the treatment of gastrointestinal and extra-gastrointestinal diseases. J Physiol Pharmacol. 2015;66:483-91. 
160. Vrieze A, Van Nood E, Holleman F, Salojärvi J, Kootte RS, Bartelsman JFWM, et al. Transfer of intestinal microbiota from lean donors increases insulin sensitivity in individuals with metabolic syndrome. Gastroenterology. 2012;143:913.

161. Goodrich JK, et al. Human genetics shape the gut microbiome. Cell. 2014;159:789-99.

162. West NR, Powrie F. Immunotherapy not working? check your microbiota. Cancer Cell. 2015;28:687-9.

163. Vétizou M, Pitt JM, Daillère $R$, Lepage $P$, Waldschmitt N, Flament $C$, et al. Anticancer immunotherapy by CTLA-4 blockade relies on the gut microbiota. Science. 2015:350:1079-84.

164. von Schwartzenberg Jumpertz. R, Turnbaugh PJ. Siri, What should i eat? Cell. 2015;163:1051-2.

165. Siddharth J, Holway N, Parkinson SJ. A western diet ecological module identified from the "humanized" mouse microbiota predicts diet in adults and formula feeding in children. PLoS ONE. 2013;8:e83689. http://dx.plos.org/10.1371/journal.pone.0083689.

166. Pinzone MR, Celesia BM, DiRosa M, Cacopardo B, Nunnari G. Microbial translocation in chronic liver diseases. Int J Microbiol. 2012;2012:694629.

167. Schwiertz A, Taras D, Schäfer K, Beijer S, Bos NA, Donus C, et al. Microbiota and SCFA in lean and overweight healthy subjects. Obesity. 2010;18:190-5.

168. Chen X, Fruehauf J, Goldsmith JD, Xu H, Katchar KK, Koon H-W, et al. Saccharomyces boulardii inhibits EGF receptor signaling and intestinal tumor growth in Apc(min) mice. Gastroenterology. 2009;137:914-23.

169. Venturi A, Gionchetti P, Rizzello F, Johansson R, Zucconi E, Brigidi P, et al. Impact on the composition of the faecal flora by a new probiotic preparation: preliminary data on maintenance treatment of patients with ulcerative colitis. Aliment Pharmacol Ther. 1999:13:1103-8.

170. Raisch J, Dalmasso G, Bonnet R, Barnich N, Bonnet M, Bringer M-A. How some commensal bacteria would exacerbate colorectal carcinogenesis? Méd Sci. 2016;32:175-82.

171. Lucke K. Prevalence of Bacteroides and Prevotella spp. in ulcerative colitis. J Med Microbiol. 2006;55:617-24. http://jmm.microbiologyresearch. org/content/journal/jmm/10.1099/jmm.0.46198-0.

172. Wexler HM. Bacteroides: the Good, the Bad, and the Nitty-Gritty. Clin Microbiol Rev. 2007;20:593-621. http://cmr.asm.org/cgi/doi/10.1128/ CMR.00008-07.

173. Prindiville T. Bacteroides fragilis enterotoxin gene sequences in patients with inflammatory bowel disease. Emerg. Infect Dis. 2000;6:171-4. http://www.cdc.gov/ncidod/eid/vol6no2/prindiville.htm.

174. Rautio M, Eerola E, Väisänen-Tunkelrott M-L, Molitoris D, Lawson P, Collins MD, et al. Reclassification of Bacteroides putredinis (Weinberg et al., 1937) in a new genus alistipes gen. nov., as Alistipes putredinis comb. nov., and description of Alistipes finegoldii sp. nov., from human sources. Syst Appl Microbiol. 2003;26:182-8.

175. Baron EJ. Bilophila wadsworthia: a unique gram-negative anaerobic rod. Anaerobe. 1997:3:83-6.

176. Kamada N, Seo SU, Chen GY, Núñez G. Role of the gut microbiota in immunity and inflammatory disease. Nat Rev Immunol. 2013;13:32135. http://www.nature.com/doifinder/10.1038/nri3430.

177. Baron S. Clostridium. Baron's Med. microbiol. 4th ed. Galveston: University of Texas Medical Branch; 1996.

178. Gaboriau-Routhiau V, Rakotobe S, Lécuyer E, Mulder I, Lan A, Bridonneau $C$, et al. The key role of segmented filamentous bacteria in the coordinated maturation of gut helper T cell responses. Immunity. 2009:31:677-89.
179. Eloe-Fadrosh EA, Brady A, Crabtree J, Drabek EF, Ma B, Mahurkar A, et al. Functional dynamics of the gut microbiome in elderly people during probiotic consumption. MBio. 2015;6:e00231.

180. Barcenilla A, Pryde SE, Martin JC, Duncan SH, Stewart CS, Henderson C, et al. Phylogenetic relationships of butyrate-producing bacteria from the human gut. Appl Environ Microbiol. 2000;66:1654-61.

181. Schneider H, Simmering R, Hartmann L, Pforte H, Blaut M. Degradation of quercetin-3-glucoside in gnotobiotic rats associated with human intestinal bacteria. J Appl Microbiol. 2000;89:1027-37.

182. Fisher K, Phillips C. The ecology, epidemiology and virulence of Enterococcus. Microbiology. 2009;155:1749-57.

183. Miquel S, Martín R, Rossi O, Bermúdez-Humarán L, Chatel J, Sokol H, et al. Faecalibacterium prausnitzii and human intestinal health. Curr Opin Microbiol. 2013;16:255-61.

184. Walters WA, Xu Z, Knight R. Meta-analyses of human gut microbes associated with obesity and IBD. FEBS Lett. 2014;588:4223-33.

185. van Passel MWJ, Kant R, Zoetendal EG, Plugge CM, Derrien M, Malfatti $S A$, et al. The genome of Akkermansia muciniphila, a dedicated intestinal mucin degrader, and its use in exploring intestinal metagenomes. PLOS ONE. 2011:6:e16876.

186. Rallabhandi P, Awomoyi A, Thomas KE, Phalipon A, Fujimoto Y, Fukase $K$, et al. Differential activation of human TLR4 by Escherichia coli and Shigella flexneri 2a lipopolysaccharide: combined effects of lipid A acylation state and TLR4 polymorphisms on signaling. J Immunol. 2008;180:1139-47.

187. Todar K. Pathogenic E coli. Online textbook of bacteriology. Wisconsin: University of Wisconsin-Madison Deparment of Bacteriology; 2007. p. $11-30$.

188. Darfeuille-Michaud A, Boudeau J, Bulois P, Neut C, Glasser A-L, Barnich N, et al. High prevalence of adherent-invasive Escherichia coli associated with ileal mucosa in Crohn's disease. Gastroenterology. 2004;127:412-21.

189. Kusters JG, van Vliet AHM, Kuipers EJ. Pathogenesis of Helicobacter pylori infection. Clin Microbiol Rev. 2006;19:449-90.

190. Chang AH, Parsonnet J. Role of bacteria in oncogenesis. Clin Microbiol Rev. 2010;23:837-57.

191. Patterson M. Streptococcus. In: Baron S, editor. Baron's Med Microbiol. 4th ed. Galveston: University of Texas Medical Branch.

192. Del Chierico F, Vernocchi P, Dallapiccola B, Putignani L. Mediterranean diet and health: food effects on gut microbiota and disease control. Int J Mol Sci. 2014;15:11678-99.

193. De Palma G, Nadal I, Collado MC, Sanz Y. Effects of a gluten-free diet on gut microbiota and immune function in healthy adult human subjects. Br J Nutr. 2009:102:1154.

194. Lorenzo Pisarello MJ, Vintiñi EO, González SN, Pagani F, Medina MS. Decrease in lactobacilli in the intestinal microbiota of celiac children with a gluten-free diet, and selection of potentially probiotic strains. Can J Microbiol. 2015;61:32-7.

195. Wacklin P, Laurikka P, Lindfors K, Collin P, Salmi T, Lähdeaho ML, et al. Altered duodenal microbiota composition in celiac disease patients suffering from persistent symptoms on a long-term gluten-free diet. Am J Gastroenterol. 2014;109:1933-41.

\section{Submit your next manuscript to BioMed Central and we will help you at every step:}

- We accept pre-submission inquiries

- Our selector tool helps you to find the most relevant journal

- We provide round the clock customer support

- Convenient online submission

- Thorough peer review

- Inclusion in PubMed and all major indexing services

- Maximum visibility for your research

Submit your manuscript at www.biomedcentral com/submit 